\title{
Divergent Paths of Development: The Modern World-System and Democratization in South Africa And Zambia
}

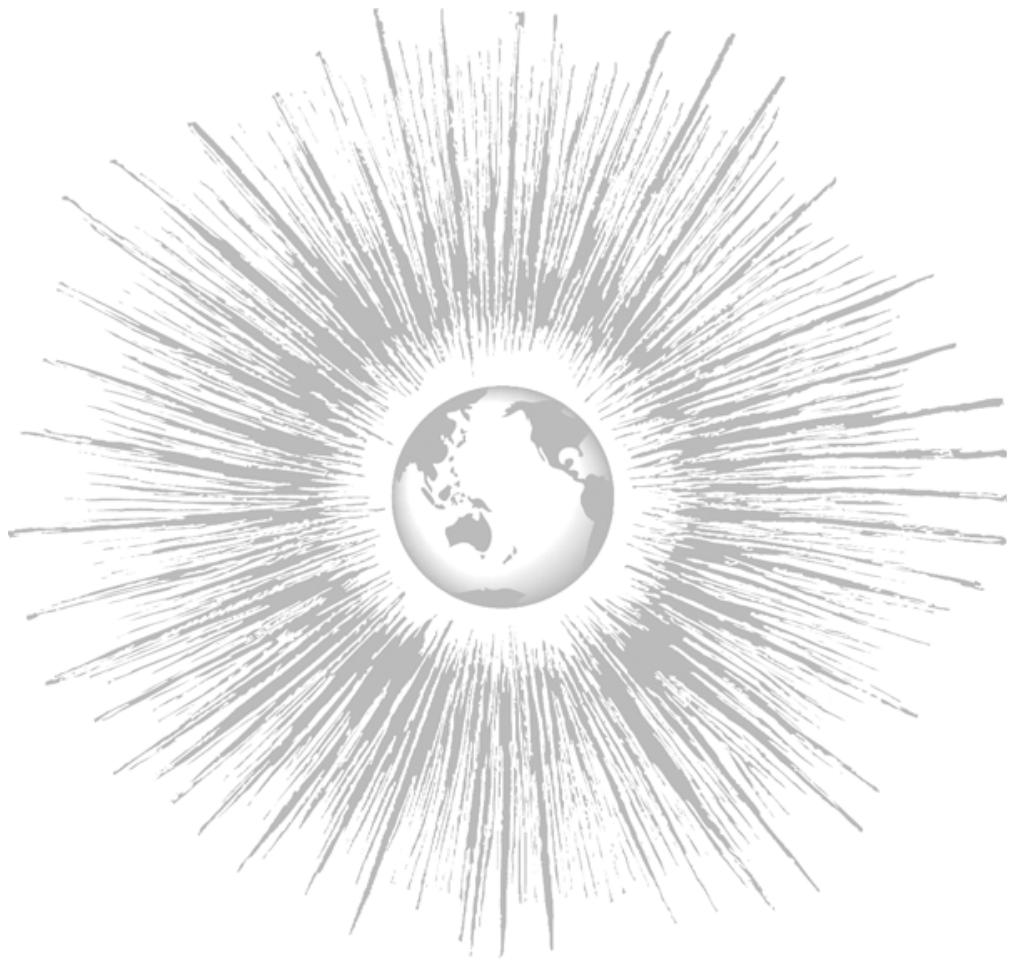

ABSTRACT

This article examines whether a Modern WorldSystems (MWS) perspective can provide an improved understanding of the processes of democratization in Africa (and other developing regions of the world) by conducting comparative case study of South Africa and Zambia in the 1990s, examining the transitions to democracy and divergent processes of democratic consolidation in each country. Semiperipheral South Africa has, due to its more advantageous position in the world-system been better equipped than peripheral Zambia to safeguard democracy against erosion and reversal. The central irony of the MWS is that the weakest states in the MWS can be pushed around by core powers and are more easily forced to democratize while at the same time they are least likely to possess the resources necessary for democratic consolidation. Semiperipheral states can maintain their independence vis-à-vis the core to a higher degree, but if the decision is made to undertake a democratic transition they are more likely to possess the resources necessary for successful consolidation. The MWS perspective allows for an improved understanding of the causal pathway of how position in the MWS translates into the ability to consolidate democracy than does approaches that emphasize domestic factors.

\section{INTRODUCTION}

The I99os constitute a watershed decade for change in postcolonial Africa as one-party states have crumbled and old authoritarian leaders have stepped down or been removed. The first few years of the I99os saw about half of the countries in sub-Saharan Africa either install, or prepare for, multiparty rule (Widner 1994:I; van de Walle 1999a:2I). Of course, not all change has been positive and it is not clear whether the current democratic wave can be sustained as the latter part of the decade has brought both severe setbacks and continued success (Bratton and van de Walle 1997:3; Diamond 1999:269-270; Baker 2000; 9). Considering the precarious nature of African democratization, it is necessary to further investigate its future prospects.

The purpose of this article is to examine whether a Modern World-Systems (MWS) perspective can provide an improved understanding of the processes of democratization in Africa (and other developing regions of the world). Can a MWS approach help explain processes of democratization within states, and can this perspective complement, improve, or replace dominant (modernization) theories of democratization? This question will be answered by first developing a MWS explanation of democratization in the non-core, secondly by tracing the incorporation into the MWS of South Africa and Zambia and each country's subsequent economic development and location in the international division of labor, thirdly by examining the transitions to democracy in each country, and fourthly by assessing the divergent processes of democratic consolidation in each country as they relate to location in the MWS.

\section{Stefan Andreasson}

Department of Political Science

Arizona State University

Tempe, AZ 85287-2001

andreasson@asu.edu

http://www.asu.edu/clas/polisci/

JOURNAL OF WORLD-SYSTEMS RESEARCH, VII, 2, FALL 200I, I75-223 bttp://jwsr.ucr.edu

ISSN 1076-I56X

(C) 2001 Stefan Andreasson 
The era of globalization makes it difficult to separate the internal and external processes that shape democratization. Thomas Koelble (1998) argues that democratization is an integral component of the Western-led phenomenon of globalization of economics, politics, and culture. To sufficiently comprehend the changes taking place both globally and within countries entails situating them in the context of the integrated and interdependent capitalist world-economy that constitutes a fundamental component of the MWS (Wallerstein 1974a; ChaseDunn 198I). The wave of liberalization and democratization that has swept across sub-Saharan Africa in the I990s ought therefore be properly understood within the context of the MWS.

The empirical components of democratization-a liberalization of politics and the exercise of multiparty elections (often accompanied by economic restructuring) - are not merely internal affairs with a genesis in societal pressures and developments within the nation-states themselves. Instead, these events are shaped and take place as a result of dynamics within the MWS that are generated through economic and political interactions between core, semi-peripheral, and peripheral zones of the system (Wallerstein 1974a; Chase-Dunn and Rubinson 1977). Democratization, thus contextualized, is often undertaken as the result of pressures from core countries of the West, including core organizations such as the International Monetary Fund (IMF) and World Bank, and is consequently subject to the approval and consent of these countries with their own economic, political and ideological interest in these events taking place (Sandbrook 1993; Grosh 1994; World Bank 1994; Young 1994). While these events could be examined by the use of dyadic interactions, the MWS perspective adds a levels of analysis dimension to our understanding of democratization and consolidation somewhat similar to Peter Gourevitch's (1978) "second image reversed" argument.

Peripheral countries often have little recourse but to conform to the wishes of core interests when it comes to undertaking economic liberalization and democratization (Sandbrook 1993; Widner 1994; Mkandawire 1999; Bond 2000). Few resources are available to non-core countries that will let them stake out their own course independent of the core. As history has shown, it becomes costly to insist on national sovereignty and self-reliance in matters of policy and, like Julius Nyerere of Tanzania, reject the neo-liberal policies championed by core countries (in the form of political liberalization and acceptance of IMF-led structural adjustment). ${ }^{1}$ The few countries still rejecting the core vision of a liber-

1. The Tanzanian economy was in dire straits and dependent on foreign aid from the midI970s onward. Economic conditions deteriorated further in the 1980s and finally, in 1986 Tanzania had to accept the IMF conditions that Nyerere had resisted since 1979 (Tordoff 1997:234). alized and democratic world, such as Myanmar, North Korea, and to a lesser degree Cuba, pay heavily for their "independence."

\section{THEORETICAL PERSPECTIVES}

\section{A. Modernization and Democratization}

The conceptualization of democracy used in this article is Robert Dahl's (1971:2-3) polyarchy, which takes into consideration three necessary dimensions of democracy; (political) opposition, (public) participation, and (law-based) civil liberty. ${ }^{2}$ Democratic consolidation, which presumes that an initial transition to democracy (however incomplete or unstable it may be) has taken place, is measured by the degree to which a society that has embarked upon a transition to democracy is able to maintain democratic rule and practices after the initial transition. This article uses Andreas Schedler's (1998:9I) definition of democratic consolidation as

making democracies secure... extending their life expectancy beyond the short term... of making them immune against the threat of authoritarian regression... building dams against eventual "reverse waves,"

thus restricting the concept of consolidation to its two negative notions: avoiding democratic breakdown and erosion. ${ }^{3}$

Consolidation of democracy is of utmost importance in any new (and fragile) democracy. In Africa, a continent with a poor democratic record and where economic crisis and societal strife often exacerbate threats to democratic survival, it becomes especially important to understand the processes of democratic consolidation and keeping a vigilant watch for the signs of democratic erosion that Schedler (1998) warns of.

Much of the literature on development, democratic transitions and subsequent consolidation emphasizes endogenous factors within the state (Lipset 1959; Lerner 1968; Huntington 1984; Hyden and Bratton, 1992; Vanhanen 1997). Barrington Moore's (1966) seminal work on comparative regime transitions

2. Dahl's (197I) definition of democracy moves beyond Josef Schumpeter (1947) and Samuel Huntington's (1989 and I99I) minimalist notions of electoral democracy that are mainly concerned with the existence of competitive elections.

3. Echoing Adam Przeworski et. al. (1996), Robert Mattes and Hermann Thiel (1998 and 95-96) argue that "consolidation has to do with the probability of sustaining democracy," and that any analysis of consolidation ought to take into account key structural correlates of democratic endurance such as national wealth, economic growth, economic equality, parliamentary government, and favorable international and regional contexts. 
stresses internal state characteristics and dynamics as the determinants of such transitions. Various incarnations of modernization theory have been prevalent in "mainstream" research accounts of the prospects for democracy in the developing world.

Seymour Lipset (1959) linked higher levels of prosperity with increased chances for democratic government. Less desperately poor people and more resources available for redistribution tends to defuse the dangerous zero-sum nature of politics that is often a major impediment to democratization and consolidation. From this perspective, development is long term, linear, and irreversible. It leads to a convergence on the Western democratic and liberal political model (Deutsch 1964; Inkeles 1964; Rostow 1964). "[E]conomic development, cultural change, and political change are linked in coherent and even, to some extent, predictable patterns (Inglehart 1997:10), and modernization theory finds support in many studies (Huntington 199I; Burkhart and Lewis-Beck 1994; Muller 1985; Muller I995a and 1995b). Adding some nuance to this understanding of the relationship between socioeconomic development and democracy, Gissinger and Gleditsch (1999:332) note evidence suggesting that income is a significant factor driving democratization at all levels (see Londregan and Poole I996:I) instead of democracy simply being a fortunate "side effect" of economic growth.

Michael Bratton and Nicolas van de Walle (1997) clearly identify endogenous forces as being primary in their conceptualization and subsequent quantitative exploration of democratic transitions. Their "politico-structural" approach emphasizes domestic political factors while at the same time giving secondary attention to structural and contingent factors (Bratton and van de Walle 1997:20).For Bratton and van de Walle (1997) a democratic transition is the result of key actors' (e.g., economic, political, and societal) abilities to arrive at negotiated agreements where each party gets at least some of what it wants. Influencing their emphasis on internal factors is their understanding that a rational choice perspective is best suited to explain political developments, an approach that is prevalent in the conventional democratization literature (e.g., Widner 1994). Bratton and van de Walle (1997:33) state that

international factors... cannot on their own account for regime change, let alone for the installation and consolidation of democracy. Instead... political transitions [are] most directly affected by domestic factors.

Fortunately MWS theory makes possible the situating of these domestic factors within the global context from which they derive, thus establishing an explicit causal path between the international and domestic factors affecting democratization. ${ }^{4}$

\section{B. The Modern World-System and Democratization}

The present MWS with capitalism as its mode of production and with a hierarchical international division of labor emerged out of the remnants of feudalism during the "long sixteenth century" in Europe and encompasses the entire world today (Wallerstein I974b:406-407). Its two basic agents are the for-profit firm and the sovereign territorial state (STS). Central to the MWS perspective is the idea that the social structure of individual societies has to be understood within the context of the entire world-system (Chase-Dunn 198I; Hopkins et. al. 1982). Consequently, changes in the larger MWS itself have significant consequences for the internal structures of areas incorporated within it (Chase-Dunn and Rubinson $1977: 454){ }^{5}$

The MWS is divided geographically into three zones of labor and export activity within the international division of labor-the core, semi-periphery, and periphery. These divisions correspond to differential development of state strength and economic characteristics of individual societies within the system (Chase-Dunn and Rubinson 1977). ${ }^{6}$ There is not, however, a separate logic for

4. The Dependency approach (to development) of André Gunder Frank (1967) emphasizes the dependency of peripheral states on core states. Guillermo O'Donnell (1979) criticizes modernization theory and highlights the influence of a peripheral state's dependency on core state's economies to endogenous state actions and class-based politics. Daniel Chirot (1977) argues that core countries affect peripheral economies (and their prospects of establishing democracy) in a negative way. Various other studies have emphasized the importance of exogenous factors in shaping the process of development, democratic transition and consolidation within states (Decalo 1992; Rueschemeyer, Stephens and Stephens 1992; Koelble 1998; McGowan and Ahwireng-Obeng 1998a and 1998b). Theda Skocpol (1973) argues for the importance of an intersocietal perspective bridging the gap between endogenous and exogenous theories of regime transitions by integrating Moore's (1966) domestic class analysis with the central ideas of Dependency and Modern WorldSystems theories.

5. "A world-system is a social system, one that has boundaries, structures, member groups, rules of legitimation, and coherence. Its life is made up of the conflicting forces which hold it together by tension, and tear it apart as each group seeks eternally to remold it to its advantage. It has the characteristics of an organism, in that it has a life-span over which its characteristics change in some respects and remain stable in others. One can define its structures as being at different times strong or weak in terms of the internal logic of its functioning" (Wallerstein 1974a:347).

6. Inequalities in the world-system between core and periphery tend to be of a permanent character and are increasing. Walter Rodney (1972:22) notes that the asymmetrical relationship based on exploitation of the periphery by the core has resulted in development in the core and underdevelopment in the periphery (cf. Frank 1966). While absolute levels of wealth may increase system-wide, the relative difference tends to be reproduced through a process of unequal exchange whereby surplus value produced in the periphery is accumulated in the core (Chase-Dunn and Rubinson 1977:460). The increasing gap between rich and poor nations that, according to MWS theory, is a result of polarization within the system is subject to some debate recently. 
economic and political forces, world-capitalism and the interstate system, within the MWS. There is only one logic of capital accumulation in which the economic and political components make up opposite (and complementary) sides of the same coin. Economic and political developments are considered to be inseparable (Chase-Dunn 198I). Illustrating the relationship between economy and politics, Immanuel Wallerstein (1974a:16) notes that

[i]n a capitalist world-economy, political energy is used to secure monopoly rights (or as near to it as can be achieved). The state becomes less the central economic enterprise than the means of assuring certain terms of trade in other economic transactions.

Kiren Chaudhry (1993:247) notes that markets are conscious constructs, not the "natural" or "neutral" phenomena that some neoliberal market adherents would suggest. Neoliberal theories of economic development often tend to ignore international (economic) developments that seriously impact the ability of developing countries to control and sustain their economies (Chaudhry 1993:247-248). This interplay between politics and economics is imperative to understand how core developments in the MWS can impact not only the economies, but also political processes, of non-core states.

The MWS approach yields a different understanding of the link between development and democracy than does modernization theory. Instead of assuming a linear process of development and democratization, MWS theory is better suited for explaining how countries embarking on a process of democratization often end up in the quasi-democratic limbo that Richard Joseph (1997) and Crawford Young (1999) call a "halfway house." This is a frequent result for semi-peripheral countries such as South Africa (cf. Joseph 1999 on "virtual democracy"). Both modernization and dependency approaches to development understand an intermediary (or semi-peripheral) position in the world economy as temporary. For modernization theorists this intermediary position is a transitional phase in a country's path from backwardness to modernity. For dependency theorists the intermediary position is a residual one. Countries will eventually be pulled into the core or (more often) the periphery due to the polarizing tendencies of development and underdevelopment in the world economy (Arrighi and Drangel 1986:10).

While a 1999 report by the United Nations Development Programme shows that the ratio of the income between the quintile of the world's population living in the richest countries and the quintile in the poorest countries has increased from 30:I in 1960 to 60:I in 1990 and 72:I in 1997, a recent study by the Norwegian Institute of International Affairs (Melchior et. al. 2000, 2-3) argues that when global income inequalities are adjusted for purchasing power they have for the most part decreased since the I960s.
Christopher Chase-Dunn (1975) finds support for a dependency perspective rather than neoclassical and modernization theories in explaining uneven development in the world economy. Chase-Dunn's argument contrasts with that of modernization theory, which tends to assume that increasing foreign (capital) penetration in non-core countries will lead to increased resources, i.e., capital and technology, available for societal development (Chase-Dunn 1975:725). Keeping in mind Lipset's (1959) link between economic development and democracy, development along modernization theory assumptions should also increase the likelihood of democratic governance in non-core countries penetrated by foreign capital. Clearly the long history of coexistence of profitable foreign corporations and non-democratic governance in Africa and elsewhere in the non-core contradicts this basic modernization assumption. The notion that "foreign capital must be seen as a form of control as well as a flow of resources" (Chase-Dunn 1975:735) is still highly relevant and often marginalized by current neoliberal thinking on the role of international financial institutions (IFI's) and international capital in processes of economic development (and democratization) in non-core countries. $^{7}$

Ironically, most African countries adopting neoliberal prescriptions for enhancing economic growth today might experience significant reductions in living standards in the short term. Thus support for democracy risks being undermined before there is any economic growth to sustain democracy as expected by modernization theory (Baker 2000:14). Clearly a MWS approach is well suited for explaining this kind of perpetuation of underdevelopment in the non-core.

\section{The Role of the Core in Promoting Democratization}

It is generally assumed that the recent "wave" of democratization in the Global South during the I99os has benefited from Western core countries push-

Lipset (1959) and Lerner (1968) initiated the development paradigm connecting democratization to economic growth and modernization. Frank (1967), Wallerstein (1984 and 1993) and others have emphasized global capitalism as a cause for underdevelopment and thus shifted the focus of democratization from internal to external factors. Dahl (1971), Diamond et. al. (1989-89) and others have connected democratization to various historical, social, structural, and cultural factors.

Others emphasize domestic action taken by national actors, such as the strengthening of state capacity through liberalization of economic structures, maintenance of social and political order while not infringing upon basic rights and improving accountability and rule of law while at the same time controlling corruption. Democratic governance, e.g., strengthening political parties and their ties to society, invigorating civil society and ensuring the autonomy of legal and political institutions, is also integral to democratic consolidation (Diamond et. al. 1997:xviii). 
ing for democracy worldwide. From a MWS perspective one could, however, question whether it really is in the interest of core countries that semi-peripheral and peripheral countries democratize. Could exploitation of the non-core not be better facilitated by dealing with authoritarian rulers rather than democratically elected ones with some responsibilities towards their citizenry?

The argument that it is in the interest of the core to push for democracy in the non-core can be supported with reference to the literature on democratization. Along with the push for democracy come demands for "good governance" (Hyden and Bratton 1992; World Bank 2000, Ch. 2). It is not necessarily clear that the "good governance" stemming from neoliberal political and economic reforms is as beneficial to people in non-core countries as it is for core investors. In fact, it might be argued that the "virtual democracy" that is often the result of democratizing efforts in the non-core mainly serves the interests of core countries and capital interests [e.g., the interests of multinational corporations (MNC's) via the policy demands of IFI's such as the IMF and World Bank]. The "virtual democracy" has a formal basis in citizen rule but key decision-making is insulated from popular involvement and oversight. Where popular participation is widened, policy choices and outcomes are narrowed. Political incumbents use violence and electoral fraud to manipulate the political transitions in order to relegitimize their power. External actors only encourage multiparty elections when such elections will not threaten vested domestic and foreign interests (Joseph 1997:367-368 and 1999b:60-63).

It is in the post-Cold War era that core support for democracy becomes especially convenient for core economic interests. "Now that global capitalism has no economic rivals, the institutional certainties of democratic governments are usually preferred to the arbitrariness of autocratic rule." Furthermore,

while the core institutions and practices of contemporary democracy rest on the premise of a free play of ideas and interests, certain substantive policy outcomes are ruled out, and others are assured. Participation may be broad, but policy choices are narrow (Joseph 1997:367).

Thus it is "safer" for core powers and economic interests to demand democracy in the non-core today. The likelihood of democratizing countries implementing policies that radically deviate from the current version of the "Washington consensus" is greatly reduced due to the economic and political leverage of core governments and institutions. ${ }^{8}$ Countries in Africa that have moved in a democratic direction during the I990s are often at the mercy of IFI's and Western governments as these African nations require continued aid and foreign direct investment (FDI) to sustain development efforts essential to maintaining some societal stability and thus the possibility of democratic consolidation (Mair 1996).

Empirical evidence supports the claim that the core is pushing democratization in the non-core. While being careful when discussing political prescriptions, emphasizing that "African countries have to determine the political structures that suits them best," the World Bank sees democratization (discussed in terms of "governance") of African states as crucial for economic development.

Democracy can have many faces, but some general principles must be shared by all: constitutional government, respect for human rights, adherence to the rule of law, and freedom of expression and association" (World Bank 2000, 66).

Kick et. al. (2000:137) note that "[t]he democratization agenda is fully supported by a range of [core dominated] supranational agencies with considerable persuasion and coercive potential (e.g., U.N., NATO, World Bank)," and van de Walle (1999b:97) emphasizes that (core) "international market forces" and "their privileged agents in Africa, the IMF and the World Bank" largely control the policy choices available to democratizing nations. Joseph (1997:368-369) attributes democratization in Africa during the I990s to three factors: prolonged fiscal crisis, the increasing control of (African) economic policy-making by IFIs and Western bilateral agencies, and "the shift of western powers (especially the United States) after the end of the cold war from tolerance of and alliance with authoritarian regimes to liberalization of their systems" (cf. Young 1999:32). While several authors point to a significant variation in outcomes of the general democratization agenda (Peters 1995; Goma and Font 1996; Huber 1996), they also note some common trends in the periphery (Clapham I996; Schwartzman 1998).

Most notable among these is that core economic and political-military programs to "democratize" the non-core gradually have reduced the number of authoritarian regimes the world over (Kick et. al, 2000\$137).

8. The "Washington consensus" represents the collection of developmental policies promoted by Western nations and the Bretton Woods institutions (the IMF and the World Bank). It has been reformulated during the latter half of the I990s to take into consideration a broad array of actors, including the state, while strongly retaining an emphasis on the role of private actors and markets (Broad and Cavanagh 1999). The central prescription for development emanating from the World Bank (2000) is a call for continued emphasis on trade, diversification, and increasing competitiveness. 
Both the U.S. and the European Union (EU), the key political and economic actors in the core, have unequivocally been proclaiming their support for democracy worldwide in the post-Cold War era. The United States Africa Growth and Opportunity Act (AGOA) designates 35 African countries as eligible for trade benefits - specifically a "most liberal access to the U.S. market" - as of January 200I. The AGOA requires countries to liberalize both their political and economic systems to gain eligibility. Countries, like South Africa and Zambia,

determined to have established, or...making continual progress toward establishing the following: market-based economies; the rule of law and political pluralism; elimination of barriers to U.S. trade and investment; protection of intellectual property; efforts to combat corruption; policies to reduce poverty; increasing availability of health care and educational opportunities; protection of human rights and worker rights; and elimination of certain child labor practices are eligible for AGOA benefits (AGOA 200I).

The U.S. Agency for International Development (USAID) explicitly states as one of its goals to:

"promote principles of democratic governance and provide technical assistance to newly formed democracies. USAID works to encourage democracy in developing nations throughout the world partly on the intrinsic values which rests in the ideals of liberty, personal and civic freedom, and government of, for, and by the people..."

USAID also emphasizes that "[p]olitical and economic reforms must go hand in hand if either is to succeed" (USAID 200I). Across the Atlantic, the European Commission's European Initiative for Democracy and Human Rights (EIDHR) "illustrates the commitment of the European Union to assisting in the global effort to build and reinforce pluralist and democratic society, governed by the rule of law, and respecting human rights" (European Commission 2000:5, 8-10).

Kick et. al. (2000) understand the push by core actors for democracy in the non-core not merely as an altruistic means to promote development, but also as a self-serving means to legitimizing existing inequalities in non-core countries that the core does business with. For example, conducting business that might generate good corporate profits but results in little if any sustainable development in a country still marred by extreme income inequalities and widespread poverty (e.g., South Africa) is less objectionable when its government has made a transition to democracy. Once a democratic transition has taken place, economic policy decisions can be referred to as the "will of the people" via their representatives in government no matter what the actual results of these policies are for the general populace.
This line of reasoning fits well with the idea that the MWS, and thus the core whose interests the MWS mainly serves, depends on some degree of stability and maintenance of three zones of development where the periphery is most accessible for exploitation and the semi-periphery guarantees some stability and protection against overwhelming polarization within the world-system (Wallerstein 1979:60-6I; Arrighi and Drangel 1986:9-10). The core needs noncore zones available for exploitation and such a state of affairs might be more easily maintained if the perpetuation of inequality and underdevelopment is obscured by some degree of democracy. With regard to overall core impact on democratization and other political developments in the non-core, Kathleen Schwartzman (1998:179) sees core actions as having "inescapable ramifications for the economic and political regimes of non-core nations... [D]omestic political structures become part of the evolving transnational fabric of economic relations." Her argument supports this article's emphasis on the importance of situating processes of democratization in non-core nations in a global context.

\section{Labor, Class, and State}

Core areas are characterized by strong states and an economy that is based on capital-intensive, high-wage, high-technology production that tends to involve relatively low levels of labor exploitation and coercion. The periphery is characterized by weak states and labor-intensive, low-wage, low-technology production that tends to involve relatively high levels of labor exploitation and coercion, such as slavery in the $18^{\text {th }}$ century. The semi-periphery contains both core-like and periphery-like economic activities and political structures (Wallerstein I984, 6I; Shannon 1996:33). Importantly, the nature of a state's economy will, to a high degree, determine the resources available in the pursuit of democratization (Diamond 1999:78).

The bourgeoisie is generally strong in core countries and weak in the periphery where economic stagnation (and collapse) and colonization have prevented its growth and entrenchment. Barrington Moore (1966:418) asserts that" a vigorous and independent class of town dwellers has been an indispensable element in the growth of parliamentary democracy. No bourgeois, no democracy." The strong class of capitalists that can be a driving force of economic and democratic development has not developed in most African countries and other peripheral regions of the world (Sandbrook 1985 and 1993; Bates I994:19-2I).

State strength tends to vary with position in the MWS, with strong states in the core and weak to nonexistent ones (colonies) in the periphery (Wallerstein 1974a:349). State strength is related to state capacity and should not be confused 
with state size, its degree of centralization, or its ability to repress and control society when results are not optimal from the perspective of its ruler's interest in economic development ( $\mathrm{cf}$. the concept of governance in Hyden and Bratton 1992).

\section{METHODOLOGY}

\section{A. Case Selection}

The basic unit of analysis in MWS theory is the world-system itself (Wallerstein 1974a). Thus the two cases selected for this study are states existing within this world-system, South Africa and Zambia. The time frame of the study is the last decade of democratic transition and consolidation in the two countries, roughly 1990 to the present. This controlled comparison case study is informed by John Stuart Mill's "method of difference," where an investigator examines paired observations in two or more cases and determines whether different outcomes are congruent or incongruent with a theory's predictions (Lijphart 197I and 1975; van Evera 1997:23).

The selection of South Africa and Zambia contrasts certain historical, politi$\mathrm{cal}$, and socioeconomic characteristics. The two countries vary in one important aspect concerning the MWS perspective; South Africa is located in the semiperiphery of the MWS and Zambia is near the bottom of the periphery. In terms of outcomes of the democratization processes (consolidation), it appears that South Africa has been able to strengthen its democracy while Zambia has experienced serious problems in terms of maintaining its fledgling democracy.

\section{Locating Countries in the MWS}

In order to make the argument about divergent trajectories in South Africa and Zambia, the position of each country in the global division of labor must be clearly established. This can be done by reference to the literature on the position of countries in the MWS and by examining relevant differences in national economic characteristics. Based on the existing literature and data on the South African and Zambian economies (see the empirical section) it is possible to make a distinction between positions of the two countries in the MWS.

While there are some disagreements on exactly how to measure the semiperiphery and which countries belong in it, a clear precedent exists for designating South Africa as semi-peripheral and Zambia as peripheral. David Snyder and Edward Kick's (1979:1110) designation of South Africa as a core country together with the United States, Japan, West Germany and others is perhaps the least useful for this project. Snyder and Kick's (1979) "block model" measures trade, interventions, diplomats and treaties in 1965 . This model exaggerates the role of South Africa by focusing on its economic and geo-strategic role at perhaps the height of Pretoria's influence regionally and is in any case of little use for understanding South Africa's role in the global division of labor in the I99os. Other measures are more instructive for the purposes of this article.

C. P. Terlouw's (1993) measure of "mean coreness" based on economic, military and political factors gives South Africa one of the lowest "degrees of coreness" among countries he include as being semi-peripheral. ${ }^{9}$

Others are more explicit about South Africa's role in the semi-periphery. Giovanni Arrighi and Jessica Drangel $(1986,69)$ make a clear distinction between South Africa as an "organic member" of the semi-periphery and Zambia as an "organic member" of the periphery throughout the 1938-1970 period measured. Arrighi and Drangel (1986) utilize Gross National Product (GNP) per capita measures when locating countries in the global division of labor, as does this article when highlighting economic differences between South Africa and Zambia (see especially tables I, 6, and 7).

Patrick McGowan and Fred Ahwireng-Obeng (1998b) make a strong case for South Africa being a regional hegemon due to its role as the only semiperipheral economy in an otherwise peripheral region (including Zambia). They argue that patterns of commodity trade are the best indicator of a country's role in the global division of labor (1998b:173-177). Similarly, William Martin and Wallerstein (1990, 103) label South Africa a "stable member of the semi-periphery" based on its economic relationships with the periphery and core. Following these authors, economic data on trade characteristics, specifically data on export and import patterns in tables 2 and 4 , are used in this article to locate South Africa in the semi-periphery and Zambia in the periphery.

\section{B. Key Variables}

The independent variable is the state's location in the MWS that is determined by measuring its economic characteristics, specifically the nature of its exports and imports. Particularly important to the causal connection between location in the MWS and democratic consolidation in individual countries is the degree of economic vulnerability, and thus susceptibility to external pressures for change,

\footnotetext{
9. Terlouw (1993:99) measures part in world trade, stability of trade relations, GDP per capita as part in world total GDP for the inhabitants of each state, military power, number of embassies sent and received by a state and number of diplomats sent and received by a state.
} 
that characterizes the state in core, semi-peripheral and peripheral regions of the MWS. ${ }^{10}$

The intervening variables are the state's nature of class relations, civil society, and state strength that are derived from its location in the MWS. These variables are of a "political" nature and thus distinct from the "economic" nature of the independent variable (location in the MWS). The nature of class relations and civil society will be described through examination of the events leading to democratic transition in each country and the role played by domestic and external actors. State strength will be measured by examining the availability of politi$\mathrm{cal}$ and economic resources in each country to resist core pressures, and thus acquire some "ownership" of the democratization process, and to contain domestic upheavals.

The dependent variable is degree of democratic consolidation that is ultimately affected by the state's location in the MWS. Political and societal developments following the initial transitions to democracy will provide the basis for judging the degree to which each country's government has been able to avoid relapse into non-democratic practices and instead consolidated its democratic achievements by holding successive free and fair multiparty elections and upholding political rights and civil liberties.

\section{Causal Argument and Hypotheses}

A set of predictions can be made based on the identification of variables. These predictions constitute the two hypotheses to be tested in this article and are derived from the divergent trajectories of democratic consolidation expected to be found in states located in different zones of the MWS. Empirical inquiry will serve to confirm or refute these theory-driven hypotheses.

Hypothesis I: it is predicted that a semi-peripheral state will be able to exercise a significant degree of independence by resisting core pressures and because semi-peripheral status enables it to diffuse some of the political and economic costs associated with democratization onto its peripheral neighbors. Compared to peripheral states, the semi-peripheral state will have more resources and a stronger civil society and state available to facilitate democratic consolidation once a transition to democracy takes place.

10. Historical background variables held constant across cases-e.g., British colonial heritage, location in Africa, majority Bantu populations, ethno-linguistic fragmentation, high degrees of income inequality, and so on-cannot explain the outcomes of the dependent variable. Instead, it is variation on the independent variable (location in the MWS) that is predicted to explain variation on the dependent variable (democratic consolidation).
Figure 1 - Location in the MWS and its Impact on Democratic Consolidation

\begin{tabular}{lll}
\hline & Semi-Periphery & Periphery \\
Democratization & Ability to resist & No ability to resist \\
Consolidation & Resources to succeed & Insufficient resources to succeed \\
\hline
\end{tabular}

Hypothesis 2: it is predicted that a peripheral state will not be able to exercise independence and resist core pressures. Location in the periphery precludes the state from diffusing political and economic costs associated with democratization to other states; instead it has to deal with all the pressures of democratization and consolidation by itself, which it is particularly ill-equipped to do. A peripheral state will more easily be pressured into democratic transition but will be less likely, due to insufficient resources, to consolidate its democracy once it is installed.

Figure I provides a conceptualization of the two hypotheses to be tested in this article.

\section{EMPIRICAL EVIDENCE}

\section{A. Incorporation into the Modern World-System}

\section{South Africa}

European settler origins in what is today the Republic of South Africa began with the arrival of Jan van Riebeeck at the Cape as governor for the Dutch East India Company in 1652 (Chase 1967:5-6). The actual incorporation of South Africa into the periphery of the MWS began around 1800 in terms of production processes with the Cape producing wool and Natal producing sugar for Great Britain (Chase 1967; Wallerstein 1986:139).

Industrialization commenced at an increasingly rapid pace with the discovery of diamonds in the Free State in I87I and gold on the Witwatersrand in I886 (Stadler 1987:36-38). It is not clear that South Africa had become a semiperipheral country at the time of the Union of South Africa in 1910. However, the global depression of the 1930s, along with the subsequent manufacturing for the war effort, provided the impetus for increased import-substitution industrialization in South Africa and thus generated an indigenous industrialist and capitalist class (classically capital in South Africa had three factions: mining, industry, and farming) which ensured that South Africa emerged out of WW II as a thoroughly semi-peripheral nation (Stadler 1987:58-59; Martin and Wallerstein 1990:102-103). 
South Africa became a major force in southern Africa after the Second World War... [T] he political structures which evolved in South Africa were complex and atypical of other colonial settlements in the region. Unlike territories in other parts of Africa, where direct colonial rule persisted until after the Second World War, South Africa enjoyed effective political independence from metropolitan powers from the beginning of the twentieth century. South Africa's economy is largely controlled by domestic forces (Stadler 1987:10).

\section{Zambia}

Incorporation of Northern Rhodesia (Zambia since independence in 1964) began with the mining activities of the British South African Company throughout its southern African territories in the early years of the $20^{\text {th }}$ century. Northern Rhodesia attained British protectorate status in I9II, and at first the territory served as a mere labor reserve for Southern Rhodesia (now Zimbabwe) and South Africa. During the I920s copper mining was intensified in Northern Rhodesia's "copper belt" and the territory became an important mining economy (Chiwele 1996, 2II). Colonial policies apparently discouraged the development of agriculture and manufacturing which resulted in the very high dependence on revenues from copper exports at Zambian independence (Klepper 1979; Seidman 1979).

Typical of a peripheral economy the wealth generated by copper mining did not stay in the country. The Northern Rhodesian economy had recovered from the Great Depression by 1935 and the mines boasted a profit well above 4 million British Pounds by 1937. Of these profits Northern Rhodesia kept only about 13-I4 percent by way of taxation while the rest of the wealth went to Britain, the British South African Company and overseas shareholders. At the same time Northern Rhodesia's African population (approximately 97 percent of the total population) had not one secondary school as the territory, according to colonial authorities, was too poor to afford one (Davidson 1994, 50).

\section{B. Economic performance since World War II}

\section{South Africa}

After nearly two decades of sustained growth, the apartheid economy began to falter in the mid-I970s. The relative calm in South African society during the height of apartheid was replaced by wildcat strikes in the I970s, the Soweto uprising of 1976, and other major riots in urban South Africa in 1980, 1984, and 1985 (Stadler 1987:1). The rise of a black urban wage class in South Africa in the I970s was on one hand a result of the country's need to remain competitive in a tighter world-economy. At the same time, this urban wage class became the source of militant trade unionism and the wave of strikes that emerged in the
I970s and was in part the catalyst for the widespread urban political conflict of the I980s (Martin and Wallerstein I990:105). Robert Price (199I) notes that apartheid developed into a serious liability for South African economic performance. By the time of the National Party (NP) victory in 1948, South African industry had become thoroughly reliant on cheap black labor, including forms of skilled labor required by the complexities of an industrial economy, and there would be no turning the tide (as was the intent of the apartheid "visionaries") regarding this basic fact.

Dependence on black labor made black townships a more or less permanent feature in and around South Africa's white cities. Attempts by the apartheid regime to discourage such permanence of blacks in "white South Africa" merely served to exacerbate the hardships of township life, which in the end would create a fertile ground for unrest and huge expenses for the apartheid regime when it finally accepted the reality of blacks in South Africa and decided to upgrade township conditions. Black industrial labor meant black proletarianization and collective organization, which ultimately would lead to demands for political inclusion (Price 199I). From this point on South African government policies were at constant odds with the country's role in the international division of labor.

The two decades following the 1973 oil crisis were, despite a few minor upswings, overwhelmingly negative in terms of South African economic performance. An average Gross Domestic Product (GDP) growth rate of 6 percent in the 1960 s declined to an average of I.8 percent in the I 980 s and eventually became negative (-I.I percent) in the early I990s. The South African economy of the I980s and early I990s was characterized by a plunge in gross fixed investment, high rates of capital flight, low rates of private savings leading to plant underutilization and declining competitiveness, low levels of private savings, very high unemployment, and chronic balance of payments difficulties (Gelb 1991:6 and 1994:3-4).

$[\mathrm{T}]$ he crisis reflected the break-down of the post-war accumulation strategy based on primary product exports and inward industrialization (including import substitution), based on a violently regimented labour supply... It also imposed structural limits on the growth of domestic demand, inhibited productivity and led to a severe shortage of skilled labour (Marais 1998: IOO-IOI).

\section{Zambia}

Despite some significant fluctuations in economic performance, Zambia remained peripheral during both its colonial and independence eras. Much like other African nations, Zambia inherited economic and political disadvantages, being "nearly devoid of indigenous owner-producers [a capitalist class] at inde- 
pendence," stemming from its previous existence as a British colony used as a means of enrichment for the metropole (Denemark 1991:538). While Zambia experienced a strong economic upswing during the first decade after independence, an upswing propelled by copper exports that made up 90 percent of its export revenues (Esomba 1995, 95), the colonial legacy combined with governmental mismanagement perpetuated the weakness of the Zambian state and the high vulnerability of its economy (Hamalengwa 1992; Ihonvbere 1996).

Nationalization of the Zambian mines in the late I960s, coupled with mismanagement and corruption of the state mining company, eventually led to declining productivity and profits (Bratton 1994:105). As a result of declining copper prices, deteriorating terms of trade, disinvestments in key sectors and drought, Zambia's "GDP growth declined from 3.7 percent per annum in the early I970s to an average of only I.O percent in the 1974-1990 period" (South African Department of Finance 1998).

While diversification of export earnings away from copper, and the promotion of the agricultural sector which absorbed the bulk of employment, had both been primary stated government objectives since independence...government investment and pricing strategies had done little to bring them about. Agricultural growth lagged behind the rest of the economy... and agricultural exports were negligible despite considerable potential (Jones 1994:26).

The inherent danger of Zambia's dependency on copper exports became evident as the commodity price crisis emerged during the I980s.

Zambia's main economic strength became a costly liability in an increasingly interdependent global economy leading to a series of four standby agreements with the IMF between I97I and 198I, loans from the World Bank between 1973 and 1976 , and a belated effort at reforming the national economy beginning in 1985 (Bratton 1994:104-107). As Zambia became beset by foreign debt and decreasing revenues, IMF loans became increasingly conditional. Zambia would have to liberalize and adjust in order to receive more help (Esomba 1995:96). In 1999 Zambia spent 13.9 percent of GDP on debt servicing, up from 6.2 percent in 1990 . By contrast South Africa spent nothing on debt servicing in 1990 and 3.7 percent of GDP in 1999 (UNDP 2001:196-197). These developments are illustrative of how weak peripheral countries, dependent on core (economic) actors such as the IMF, are less resistant to external pressures for liberalization and democratization and thus less "in charge" of their own policies.

Table I illustrates persistent economic problems in both South Africa and Zambia. Both countries have experienced an overall decline in per capita GDP in the last twenty-five years. This is consistent with the United Nations Development Programme (UNDP 1999) labeling South Africa as one of the countries making
Table 1 - GDP Per Capita, 1975-1998*

\begin{tabular}{lrrrrrl}
\hline & & & & & $\begin{array}{l}\text { Average Annual } \\
\text { Change (\%) }\end{array}$ \\
South Africa & 1975 & 1980 & 1985 & 1990 & 1998 & $1975-98$ \\
Zambia & 4,574 & 4,620 & 4,229 & 4,113 & 3,918 & -0.7 \\
Sub-Saharan Africa & 641 & 551 & 483 & 450 & 388 & -2.2 \\
High Income Countries & 699 & 692 & 629 & 614 & 578 & \\
World & 17,673 & 20,192 & 22,082 & 25,284 & 28,400 & \\
\hline
\end{tabular}

* 1995 US\$

Source: United Nations Development Programme (2000:178-I8I)

slowest progress in human development among countries starting with medium human development and Zambia making the slowest progress in human development among countries starting with low human development. ${ }^{11}$

\section{Current Location in the Modern World-System}

A state's location within the international division of labor can be determined by assessing the standard characteristics of a state's economic activities as reflected in the nature of its exports and imports (Wallerstein 1974a and 1974b; McGowan and Ahwireng-Obeng 1998a and 1998b). The economies of South Africa and Zambia differ on many key measures. As manifested by their historical development and contemporary economic characteristics, South Africa has remained semi-peripheral and Zambia peripheral in the post-WW II era (Arrighi and Drangel 1986).

Table 2 illustrates the differences in diversification of the South African and Zambian economies. While 49 percent of South African exports stem from primary products and natural resource-intensive manufactures (a testament to the periphery-like activities that exist in semi-peripheral states) the corresponding number for Zambia is 89 percent. South Africa's economy contains a high proportion of high-technology exports; technology- and human capital-intensive manufactures make up 44 percent of its exports while they only make up 3 percent of Zambias exports. South Africa' growth in technology and human resources-intensive manufactures (I7 percent combined) is far higher than its negative growth in primary products and natural resource-intensive manufactures $(-12$ percent combined) in the period 1994-1998. Conversely, Zambia's

${ }^{11 .}$ It should be noted that the overall decline, or slow progress, of overall Human Development Index (HDI) values and rankings of sub-Saharan African states is in large part related to the current AIDS epidemic that is reducing life expectancy considerably across the continent. 
Table 2 - Indicators on Export Performance, 1998

\begin{tabular}{|c|c|c|c|}
\hline \multicolumn{4}{|c|}{ Soutb Africa } \\
\hline & $\begin{array}{l}\text { Value (US\$ } \\
\text { million) }\end{array}$ & $\begin{array}{l}\% \text { growth per } \\
\text { annum 1994-98 }\end{array}$ & $\begin{array}{c}\% \text { share in } \\
\text { exports }\end{array}$ \\
\hline Primary products & 6175 & 2 & 36 \\
\hline $\begin{array}{l}\text { Natural resource- } \\
\text { intensive manufactures }\end{array}$ & 2169 & -14 & 13 \\
\hline $\begin{array}{l}\text { Labour-intensive } \\
\text { manufactures }\end{array}$ & 1175 & 14 & 7 \\
\hline $\begin{array}{l}\text { Technology-intensive } \\
\text { manufactures }\end{array}$ & 3608 & 11 & 21 \\
\hline $\begin{array}{l}\text { Human capital-intensive } \\
\text { manufactures }\end{array}$ & 3826 & 6 & 23 \\
\hline Totals & 16593 & 19 & 100 \\
\hline \multicolumn{4}{|c|}{ Zambia } \\
\hline & $\begin{array}{l}\text { Value (US\$ } \\
\text { million) }\end{array}$ & $\begin{array}{l}\text { \% growth per } \\
\text { annum 1994-98 }\end{array}$ & $\begin{array}{c}\% \text { share in } \\
\text { exports }\end{array}$ \\
\hline Primary Products & 125 & 44 & 23 \\
\hline $\begin{array}{l}\text { Natural Resource-Intensive } \\
\text { Manufactures }\end{array}$ & 347 & -12 & 66 \\
\hline $\begin{array}{l}\text { Labour-Intensive } \\
\text { Manufactures }\end{array}$ & 40 & 13 & 8 \\
\hline $\begin{array}{l}\text { Technology-Intensive } \\
\text { Manufactures }\end{array}$ & 2 & 1 & 2 \\
\hline $\begin{array}{l}\text { Human Capital-Intensive } \\
\text { Manufactures }\end{array}$ & 5 & 7 & 1 \\
\hline Totals & 526 & 64 & 100 \\
\hline
\end{tabular}

Source: International Trade Centre (2000A)

growth in technology and human capital-intensive manufactures (i9 percent combined) is less than its growth in primary products and natural resourceintensive manufactures ( 32 percent combined) over the same time period. South Africa's economy displays growth in "core-like" sectors while Zambia's economy displays growth in "periphery-like" sectors.

Table 3 illustrates Zambia's dependence on a primary export commoditycopper-that is characteristic of many peripheral economies (they are usually
Table 3 - Dependency on Commodity Exports, 1994

\begin{tabular}{lccc} 
Country & Major Commodities & $\begin{array}{c}\text { Value of exports in } \\
\text { \$US (millions), 1994 }\end{array}$ & $\begin{array}{c}\text { Share of commodities } \\
\text { in total exports (\%) }\end{array}$ \\
South Africa & gold, minerals & 25,300 & 60 \\
Zambia & copper, cobalt & 1,075 & 84 \\
\hline
\end{tabular}

Sources: Kotelo (1995:10) and Africa Institute (1995:73-74)

"monocrop" and "monomineral"). Zambia clearly displays the economic characteristics of a peripheral state. As a country no more industrialized than most Southern African Development Community (SADC) countries (with the exception of South Africa), "[c]opper and cobalt form the mainstay of Zambia's export goods" (South African Department of Finance 1998). ${ }^{12}$

While South Africa also is dependent on mineral exports, its dependency on such exports is less serious and its economy is clearly more diversified (as befits a semi-peripheral country) than the Zambian economy. According to the South African Department of Finance (1998),

South Africa has a modern, well-diversified economy in which agriculture, mining, secondary industry (manufacturing, electricity, gas, water and construction), commerce and a broad structure of service establishments contribute to the wealth of the nation.

It is especially over the past decade that the South African economy has diversified. Growth in communications, transport, financial services, tourism and manufacturing sectors has eclipsed the former importance of the mining, quarrying, and agricultural sectors. The biggest growth has taken place in the finance and insurance sector that has grown from I4.8 percent of GDP in I99I to 20.2 percent in 2000 , making it the largest sector of the South African economy. Notably, the agriculture, mining, and quarrying sectors, traditional mainstays of the South African economy, now account for less than io percent of the country's GDP for the first time in history (The Sunday Independent 200I). Although South Africa is still dependent on exports of primary and intermediate commodities to core countries, the country's exports to the rest of Africa consist mainly of manufactured goods (McGowan and Ahwireng-Obeng 1998a and $1998 \mathrm{~b}$ ) in accordance with its semi-peripheral role in the world-economy.

12. Angola, Botswana, Democratic Republic of Congo, Lesotho, Malawi, Mauritius, Mozambique, Namibia, Seychelles, South Africa, Swaziland, Tanzania, Zambia and Zimbabwe are members of the SADC. 
Table 4 - Major Imports According to Product Group, 1995

\begin{tabular}{|c|c|c|}
\hline \multicolumn{3}{|c|}{ South Africa* } \\
\hline & Value (US\$ '000) & Value as $\%$ of $\mathrm{GDP}^{* *}$ \\
\hline Petroleum \& Crude Oil & $2,118,531$ & 1.92 \\
\hline Passenger Cars & $1,065,520$ & 0.96 \\
\hline Motor Vehicles Parts \& Access. & 985,635 & 0.89 \\
\hline Telecommunications Equipment & 894,267 & 0.81 \\
\hline Computer Equipment & 688,577 & 0.62 \\
\hline \multicolumn{3}{|c|}{ Zambia } \\
\hline & Value (US\$ '000) & Value as $\%$ of GDP ${ }^{* *}$ \\
\hline Petroleum \& Crude Oil & 79,945 & 1.97 \\
\hline Railway Vehicles \& Equipment & 23,158 & 0.57 \\
\hline Civil Engineering Plant & 23,011 & 0.57 \\
\hline Maize & 22,515 & 0.56 \\
\hline Road Motor Vehicles & 19,405 & 0.48 \\
\hline
\end{tabular}

* South African Customs Unio

** 1990 US\$ constant prices

Sources: United Nations Economic Commission for Africa (1996:173) and International Trade Centre (2000в)

There are discernible differences in import patterns between South Africa and Zambia as well. Table 4 lists the five major product groups imported to South Africa and Zambia according to value in 1995. According to the South African Department of Finance (1998), imports to South Africa consists mainly of capital goods, raw materials, semi-manufactured goods, and consumer commodities, largely from Germany, the USA, the UK, and Japan. Zambia's imports consist mainly of crude oil, chemicals, machinery, iron, steel, textiles, and vehicles, largely from South Africa, the UK, Zimbabwe, and Japan.

Table 5 shows the total numbers and percentages of the workforce that are employed in agriculture, industries, and services in South African and Zambia. Zambias workforce is concentrated in the agricultural sector (65.7 percent) as might be expected in a peripheral country, and South Africa's workforce is concentrated in industries ( 40.9 percent) and services ( 54.5 percent), which is to be expected in a more developed, semi-peripheral economy.

Aid and financial flows are another set of useful indicators of South Africa and Zambia's different positions in the MWS. Table 6 shows that net private capital flows are comparable in the two countries and that Zambia's FDI as a percentage of GNP was slightly higher than that of South Africa in 1997 (due to the impact of privatization efforts in Zambia at the time). However, Zambia's much higher external debt (at 136 percent of GNP, seven times higher than South
Table 5 - Distribution of Economically Active Population, 1997

\begin{tabular}{|c|c|c|c|c|}
\hline \multirow[b]{2}{*}{ Economic Sector } & \multicolumn{2}{|c|}{ South Africa } & \multicolumn{2}{|c|}{ Zambia } \\
\hline & $\begin{array}{l}\text { Population } \\
\text { (thousands) }\end{array}$ & $\%$ & $\begin{array}{l}\text { Population } \\
\text { (thousands) }\end{array}$ & $\%$ \\
\hline Agriculture & 622 & 4.6 & 2390 & 65.7 \\
\hline Industries & 5569 & 40.9 & 442 & 12.2 \\
\hline Services & 7426 & 54.5 & 804 & 22.1 \\
\hline Totals & 13618 & 100 & 3636 & 100 \\
\hline
\end{tabular}

Source: African Statistical Yearbook (1998)

Table 6 - Aid and Financial Flows, 1997

\begin{tabular}{lcc}
\hline & South Africa & Zambia \\
Net private capital flows & 3,610 & 79 \\
\% of GNP* & 2.43 & 2.26 \\
FDI & 1,725 & 70 \\
\% of GNP & 1.32 & 2.0 \\
External debt & 25,222 & 6,758 \\
\% of GNP* & 19 & 136 \\
Official Development Assistance & & \\
(US\$ per capita) & 12 & 65 \\
\% of GNP & 0.4 & 16.7 \\
\hline
\end{tabular}

(Million US\$ except where noted)

* GNP US\$1997, http://www.undp.org/hdro/Backmatter2.pdf

Source: World Bank World Development Report 1999/2000 (1999:27I)

Africa's) and serious dependence on official development assistance ( 16.7 percent of GNP, compared to 0.4 percent in South Africa) constitute clear evidence of Zambia's vulnerable position in the MWS (World Bank 1999:27I). Such vulnerability makes Zambia more sensitive to external pressures than South Africa as the discussion on democratization will show. The information provided in tables 2-6 is consistent with the designation of South Africa as a semi-peripheral state and Zambia as a peripheral one.

Lastly, the Human Development Index (HDI) published by the United Nations Development Programme (200I) provides an indication of the human resources available for a particular country (in its quest for development, democratization, etc.). Ranking on the HDI is predicted to be affected by a country's position in the MWS. MWS theory predicts that semi-peripheral states will 
Table 7 - Human Development Index, 2001

\begin{tabular}{|c|c|c|c|c|c|c|c|c|}
\hline 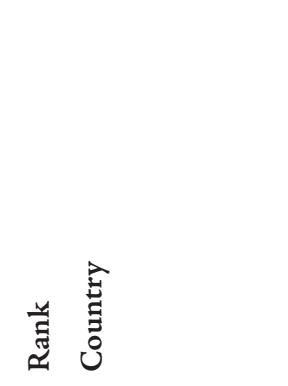 & 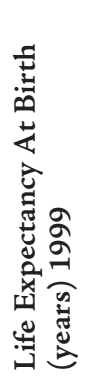 & 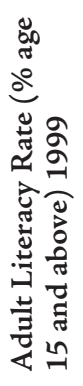 & 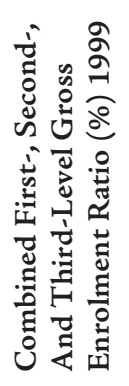 & 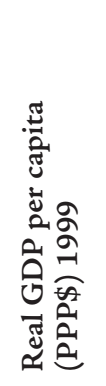 & 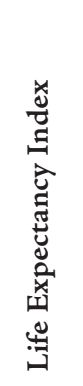 & 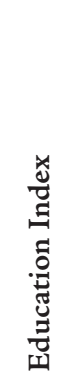 & 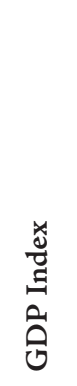 & 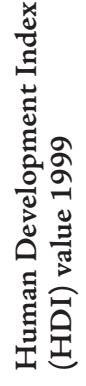 \\
\hline \multicolumn{9}{|c|}{ High Human Development } \\
\hline 1 Norway & 78.4 & 99 & 97 & 28,433 & 0.89 & 0.98 & 0.94 & 0.939 \\
\hline 20 Italy & 78.4 & 98.4 & 84 & 22,172 & 0.89 & 0.94 & 0.90 & 0.909 \\
\hline 40 Bahrain & 73.1 & 87.1 & 80 & 13,688 & 0.80 & 0.91 & 0.82 & 0.824 \\
\hline \multicolumn{9}{|c|}{ Medium Human Development } \\
\hline 60 Macedonia & 73 & 94 & 70 & 4,651 & 0.80 & 0.86 & 0.64 & 0.766 \\
\hline 80 Paraguay & 69.9 & 93 & 64 & 4,384 & 0.75 & 0.83 & 0.63 & 0.738 \\
\hline 94 South Africa & 53.9 & 84.9 & 93 & 8,908 & 0.48 & 0.87 & 0.75 & 0.702 \\
\hline \multicolumn{9}{|c|}{ Low Human Development } \\
\hline 130 Bhutan & 61.5 & 42 & 33 & 1,341 & 0.61 & 0.39 & 0.43 & 0.477 \\
\hline 143 Zambia & 41 & 77.2 & 49 & 756 & 0.27 & 0.68 & 0.34 & 0.427 \\
\hline 162 Sierra Leone & 38.3 & 32 & 27 & 448 & 0.22 & 0.30 & 0.25 & 0.258 \\
\hline Sub-Saharan Africa & 48.8 & 59.6 & 42 & 1,640 & 0.4 & 0.54 & 0.47 & 0.467 \\
\hline High income (OECD) & 78 & 99 & 92 & 26,050 & 0.88 & 0.97 & 0.93 & 0.928 \\
\hline World & 66.7 & 79.2 & 65 & 6,980 & 0.7 & 0.74 & 0.71 & 0.716 \\
\hline
\end{tabular}

Source: United Nations Development Programme (200I:I42-I43)

have a higher degree of human development than peripheral ones. As Table 7 shows, South Africa ranks better than Zambia on all components of the HDI. ${ }^{13}$ As the sections below will illustrate, position in the MWS has been of crucial importance for determining domestic characteristics and democratic trajectories in both South Africa and Zambia. Without taking position in the MWS into consideration, and its effect on domestic economies, societies and politics,

13. "[T] he HDI reflects achievements in the most basic human capabilities-leading a long life, being knowledgeable and enjoying a decent standard of living. Three variables have been chosen to represent these dimensions-life expectancy, educational attainment and income" (UNDP 1999). it becomes impossible to understand the constraints under which domestic actors operate.

\section{Transitions to Democracy}

\section{South Africa}

Early industrialization and the development of Africa's only "modern" capitalist and middle classes, initially driven by core interests, have profoundly impacted South Africa's class structure and civil society (Stadler 1987). Arguably the active role of black unions, legalized in 1979 along with other social organizations (Bendix 1996:233), played a great part in fostering a strong civil society and democratic practices among the majority of South Africans officially excluded from such associations and practices in general since the arrival of European settlers in 1652 and in particular since the introduction of apartheid in 1948. The United Democratic Front (UDF), created in 1983 as a multiracial umbrella organization bringing together labor unions, churches, student and civic organizations in the fight against apartheid, also contributed to the development of civil society among South Africans in the authoritarian apartheid state (Deegan 1999:67). The development of "modern" class relations is due to South Africa's status as a semi-peripheral state containing modern economic sectors conducive to the development of class-based organization, including the development of a significant middle class, that often proves elusive in peripheral countries.

Commentators on the South African transition to democracy such as Heribert Adam and Kogila Moodley (1993) and Patti Waldmeir (1997) highlight the importance of agency manifested in the willingness of key actors within both the African National Congress (ANC) and the NP to negotiate a transition to democracy. However, structural aspects of the "inevitability" of the transition are also evident in their accounts. They emphasize the political stalemate and untenable economic situation developed by the end of the 1980 s, the rapprochement between the NP and ANC (beginning with secret talks in the I980s and escalating with the ascendance of F. W. de Klerk to the South African presidency), and the elite pact between the NP and ANC leaderships making the final transition to democracy (the 1994 national elections) possible. In this sense, while individual actors were able to shape the outcome of the transition to a significant degree, forces "larger" than individuals moved the process itself forward. A transition of some sort was bound to take place by the early ig9os.

Hein Marais (1998) provides a somewhat pessimistic assessment of the transition to democracy. He argues that a (race-based) capitalist logic of accumulation created "two nations" - one privileged and one destitute-since the 
discovery of minerals in the nineteenth century. ${ }^{14}$ When faced with an "organic crisis" the same capitalist system facilitated a pacted transition which managed to co-opt ANC elites and thus keep capital interests privileged at the expense of real socioeconomic transformation by creating a new centrist pro-capital bloc. This reading of the transition sees the appeasement of capital as perhaps unavoidable and South Africa destined to continue on the "two nations" track (cf. Bond 2000). ${ }^{15}$ At the same time, South Africa's transition to democracy has not been at the mercy of IFI's as the transition in Zambia clearly has been.

Despite some doubts about fairness and openness (mainly in KwaZuluNatal), the 1994 South African elections were by and large considered a success and an official manifestation of the establishment of true democracy in South Africa (Reynolds 1994; Johnson and Schlemmer 1996; Butler 1998). The ANC ran on a nonracial platform and captured 62.6 percent of the votes and 255 of 400 seats in the National Assembly (Reynolds 1994).

\section{Zambia}

Zambia lacks the same history of an indigenous capitalist class and competent bureaucracy as developed in South Africa." $[T]$ he Zambian bureaucracy has a far shorter history of professionalization [and] Zambia was essentially a labor-reserve colony" until the 1960s when advanced training for Zambians began (Denemark 1991:534). Despite the relatively strong performance of the Zambian economy during the decade following independence, neglecting to invest in proper training of the Zambian bureaucracy has resulted in a poorly administered, and therefore weak, state. However, the emphasis on copper mining in the primary sector created a class-conscious proletariat and a sense of civil society reinforced by trade union practices (Hamalengwa 1992). Arguably the influence of civil society through the unions, considering that Kenneth Kaunda's successor Frederick Chiluba was Zambia’s foremost union leader,

14. South African President Thabo Mbeki has often spoken of South Africa as racially divided into "two nations." Addressing COSATU's 7th National Congress in September 2000, Mbeki stated that " $t]$ hese masses want to see an end to racism. They want to see an end to the situation in which our country is divided into two nations, one well-off and white and the other poor and black" (COSATU 2000).

15. Marais' (1998) account differs from those of Adam and Moodley (1993) and Waldmeir (1997) in that it emphasizes ANC concessions where the others emphasize NP negotiation defeat. However, Marais follows Adam Przeworski (199I) who argues that a pacted transition is necessarily a conservative one and Stephan Haggard and Robert Kaufman (1995) who convincingly argue that pacted transitions result in the old order being able to significantly influence future arrangements. played an important part in the events leading up to the I99I democratic elections (Ihonvbere 1996: Ch. 3).

The weakness of Zambia's economy, coupled with the weak state typical of peripheral regions and exacerbated by internal pressures for change (Denemark 199I), led to its acceptance of IMF structural adjustment programs (SAP's) and eventually the end of President Kaunda's one-party state (Bratton 1994, I07-108). This development is important, because countries most likely to be forced into accepting SAP's wholesale are the countries most likely to see their democratic legitimacy subsequently undermined (Mkandawire 1999, I25-130). During a crisis of political realignment Chiluba's Movement for Multi-Party Democracy (MMD) emerged as a viable opposition to Kaunda and the United National Independence Party (UNIP). The government's final loss of legitimacy was illustrated by the urban food riots of 1990 that eventually turned political (Bratton 1994:102).

Zambia became a formal democracy after Kaunda signed a constitutional amendment introducing the Third Republic in 1990 and subsequently stepped down as president after his electoral defeat by Chiluba and the MMD in October 199I. In this election, the MMD captured over 75 percent of the vote and 125 out of 150 seats in the National Assembly (Burnell 1996:407). The I991 election was widely regarded as free and fair by international observers (Bjornlund et. al. 1992; Bratton 1992; Commonwealth Observer Group 1992).

The peaceful nature of the democratic transition was applauded both domestically and internationally. Zambia was upheld as a model of transition and benefited from a large inflow of foreign aid. The inflow of aid was not only a result of the successful electoral transition, but also because Zambia's new regime had committed to economic liberalization and structural adjustment (Baylies and Szeftel 1997:II3). At the time of the initial transition to democracy, however, the World Bank (1994:58) rated Zambia's overall macroeconomic policy stance as "very poor" (in comparison to other sub-Saharan African countries) and noted that Zambia's changes in macroeconomic policies from I98I-I986 and 1987-I99I had "deteriorated." Ultimately, post-transition Zambia has been bogged down in economic stagnation and dependency and hopes for democratic consolidation seem dim.

The events leading up to the democratic transition in Zambia in I99I are an excellent example of how systemic forces both shape and interact with the internal weaknesses characteristic of peripheral states to influence domestic events and, in this case, translate into poor prospects for democratic consolidation. Thus Zambia's democratic experience cannot be fully comprehended without situating it within the context of the MWS as a whole. 
Table 8 - Freedom House, Annual Survey of Freedom Scores, 1990-1991 through 1999-2000

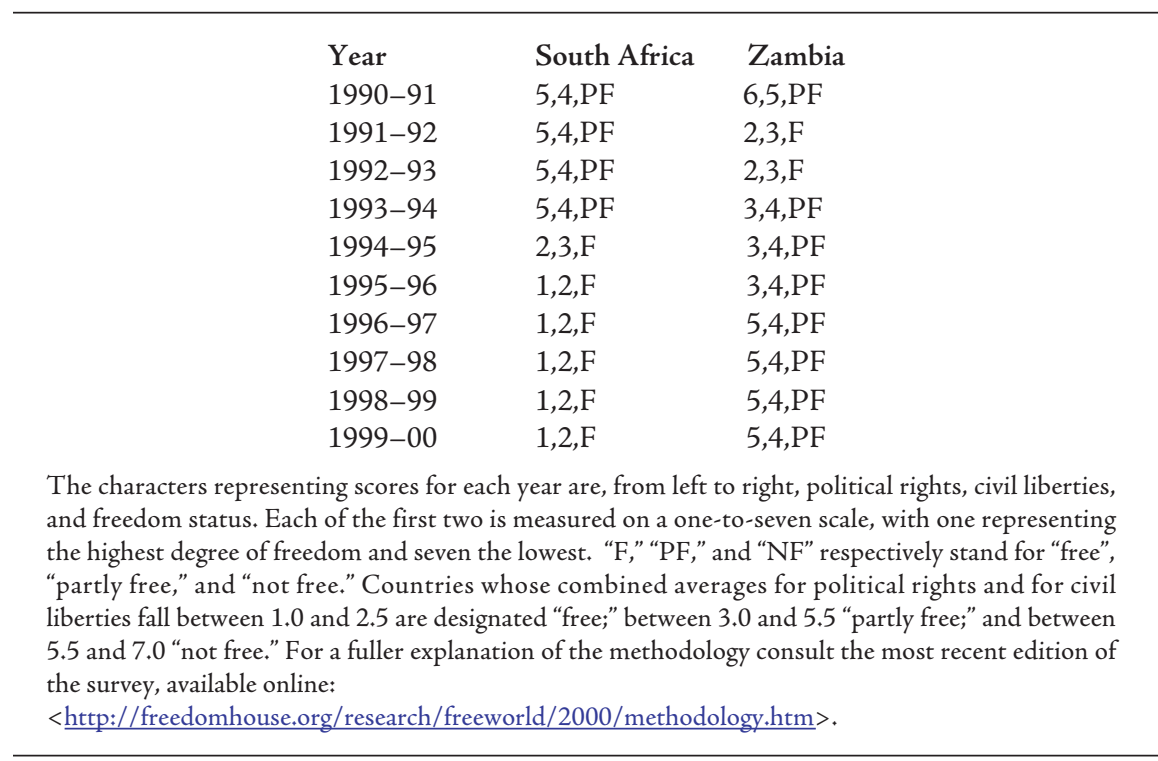

Source: Freedom House (2001)

\section{E. Consolidation of Democracyः Success and Failure}

A measure which can be used as an indicator of how a country's consolidation process is progressing is the Freedom House (2000) survey of political rights and civil liberties, which designates countries as being "free," "partly free" or "not free." While it is important to note that Freedom House measures freedom in strictly "negative" terms, i.e., the absence of government restrictions on political rights and civil liberties (any "positive" notions of freedom relating to equitable economic distribution etc. are not considered), Table 8 clearly indicates that in terms of the freedoms measured by Freedom House, South Africa has managed to maintain a society respectful of political rights and civil liberties since 1994. In Zambia the emergence of a free society in I991 has reverted back to a partly free society with significant infringements upon political rights and civil liberties that worsened at the time of the second multiparty elections in 1996. While a low (i.e., "more free") Freedom House score is not synonymous with degree of consolidation achieved, it stands to reason that a country in which political rights and civil liberties are severely infringed upon is likely to also be experiencing some of the democratic erosion, and possibly breakdown, that Schedler (1998-IO3) warns of.
Margaret Hanson and James Hentz (1999) argue that the South African government has been able to respond to core pressures for economic restructuring and appropriate these ideas as their own, thus making it restructuring on South African terms rather than "neocolonial" imposition, to a degree not possible in Zambia. The empirical evidence on democratic transition and consolidation presented here seems to corroborate Hanson and Hentz's (1999) claim and suggests that at least some degree of agreement between international actors, government, and perhaps also society on the necessity of liberalization and restructuring has emerged in South Africa but not in Zambia. Thus consolidation in South Africa is less prone to becoming complicated by serious vacillation on the reforms needed for long-term growth as demanded by the world-economy and its key actors whereas in Zambia lingering disagreements on how to liberalize and restructure are bound to further complicate the wavering consolidation process. ${ }^{16}$

Comparing South Africa and Zambia's past transactions with the IMF gives us a clear indicator of Zambia's greater economic vulnerability and dependence on IFI's, as well as the greater leverage by IFI's over Zambia's democratization process. In 1983 South Africa entered its only stand-by arrangement with the IMF, drawing 159 out of 364 SDR million approved. ${ }^{17}$ In addition, South Africa drew 6I4.43 SDR million from the IMF General Resources Account (GRA) in 1993 and repaid this amount in $1997-98{ }^{18}$ South Africa currently has no outstanding purchases or loans, nor any projected obligations, to the IMF (International Monetary Fund 200Ia). By contrast, Zambia has borrowed regularly from the IMF since 1984. Zambia drew I47.5 and I03.8 SDR million from the GRA in 1984 and 1986 respectively, an additional I485.II3 SDR million from the GRA and the Structural Adjustment Facility (SAF) in 1995, and a total of 64.94 SDR million from the SAF between 1997 and 200I. Zambia is scheduled to repay approximately 172 SDR million per year (principal and interest)

16. Patrick Bond (2000) does emphasize that South Africa's transition to democracy also has been hampered by constraints imposed by the core actors of the world economy and that the domestic discourse on appropriate policy has been conflictual. However, the conflict over policy in South Africa has not been characterized by nearly the same degree of vacillation and volatility as compared with that in Zambia.

17. Special Drawing Rights (SDR) is an artificial currency unit created by the IMF in 1996. It is used as an international reserve asset and is defined as a basket of national currencies-Euro, Japanese Yen, Pound sterling, and U.S. dollar (see http://www.imf.org/external/np/exr/facts/ $\underline{\text { sdr.htm). }}$.

18. The GRA contains the IMF's financial resources that are based on member nations' subscriptions (see http://www.imf.org/external/np/tre/activity/200I/07060I.htm). 
to the IMF through 2005. The country's outstanding purchases and loans, I8I.74 million in SAF arrangements and 716.62 SDR million in Enhanced Structural Adjustment Facility (ESAF) arrangements, constitute 37.2 percent and I46.5 percent of its quota respectively (International Monetary Fund 200Ib).

This comparison of each country's involvement with the IMF provides an appreciation of Zambia's difficulties in terms of acting independently vis-à-vis core interests and why the country's peripheral role in the world-economy has resulted in a more volatile transition to democracy than has been the case in South Africa. The dependence on core-led IFI's is more acutely felt in Zambia and thus disagreements over what economic policies are appropriate, and how IFI demands infringe on national sovereignty, are more likely to result in conflict that impedes democratization. Whereas there at times have been sharp disagreements between the ANC and its alliance partners, the Congress of South African Trade Unions (COSATU) and the South African Communist Party (SACP), on major economic policy decisions such as the move from the Reconstruction and Development Programme (RDP) to the Growth, Employment and Redistribution strategy (GEAR), the ANC has had an easier time acquiring "ownership" of its economic policies and its developmental projects than has Zambia's MMD (Hanson and Hentz 1999).

Ironically, the IMF's insistence on neoliberal policy adjustments for developing countries today follows a long period of IMF support for "statist" policies. According to George Ayittey (1998:270), IMF emphasis on conditionality and macro management reinforced notions of state control and management in Africa.

For 30 years, Zambia's statist policies of import-substitution, subsidized food prices and state enterprises were backed by western economic advisers including the World Bank. True, the IMF always disliked them, but then, as one IMF official said privately: "Why did we lend $\$ 1.2$ billion to a government whose policies we disapproved of?" (The Economist 1995:34).

\section{South Africa}

Despite setbacks and international doubts, South African consolidation has made steady, if slow, progress (Southall 2000). The second national elections in June 1999, as well as local government elections in 1995 and 2000 , have further established South Africa as a democracy able to survive internal and external pressures. The 1999 national elections saw the ANC win yet another decisive victory capturing 66.3 percent of the votes and 266 of 400 seats in the National Assembly (Friedman 1999).

Although the 1999 elections saw some realignment in the South African political arena, voting patterns still resemble societal ethnic cleavages (that also correlate with socioeconomic cleavages) where whites still support "white parties" and blacks still support "black parties." The most significant results of the 1999 elections were the decline in support for the New National Party (NNP) by two-thirds (from about 2I to 7 percent) and the rapid rise of the Democratic Party (DP) from less than 2 to almost io percent, thus making it the new official opposition. The fact that the Inkatha Freedom Party (IFP) remained in control of KwaZulu-Natal despite an offer by the ANC to name IFP leader Mangosuthu Buthelezi Deputy President in return for an ANC premiership in the province, and that the Western Cape remained in NNP hands (through a coalition with the DP) despite an ANC plurality (about 42 percent) in the province are also significant as they provide indications of significant opposition to the dominant ANC as well as the latter's ability to accept rejection and electoral defeat.

The 2000 local government elections have arguably transformed the South African political landscape into a "two-party" system with the ANC receiving 59.4 percent of votes nationwide, the Democratic Alliance (DA) — which includes the NNP, the DP, and the Federal Alliance (FA) - 22.I percent, the IFP 9.I percent (concentrated in KwaZulu-Natal) and various other parties between 2.6 and 0.3 percent each (Electoral Institute of Southern Africa 2000). The rejection in successive elections of extreme parties on the right and left, e.g., the Freedom Front (FF) and the Pan Africanist Congress (PAC), points to a preference for centrist politics and a degree of continuity among the South African electorate. This is a good omen for the future of democratic consolidation, and in terms of successful multiparty elections being one sign of consolidation South Africa's positive experience has been quite different from the reversal of consolidation occurring in Zambia between its I991 and 1996 elections.

On the other hand, successful elections are not a sufficient cause for democratic consolidation, and in South Africa consolidation has been hampered by differences between liberal and emancipatory understandings of democracy. Liberal democracy is often associated with minimalist requirements of democracy (Di Palma 1990; Huntington 1991). Emancipatory democracy entails a notion of transformation (Gould 1988; Pateman 1970) along with socioeconomic justice and fairness, deliberation of issues at the grassroots level, and participation in decision-making (Koelble 1998:34). Persistent signs that the South African citizenry does not agree on the meaning of democracy, or how it ought best to be practiced, signals potential trouble ahead for consolidation (Koelble 1998, I00; Mattes and Thiel 1998). The stark differences in understandings of what democracy means stem in part from the existence in semi-peripheral South 
Africa of both a small but significant "core" upper-middle class and a larger "peripheral" lumpenproletariat.

A 1996 IDASA survey found that 4I percent of respondents in the Western Cape, 37 percent in KwaZulu-Natal, and 29 percent nationally associated democracy with substantial improvements in their lives, thus conceiving of democracy as emancipatory. Forty-five percent of respondents nationally, 33 percent in the Western Cape and 39 percent in KwaZulu-Natal regarded democracy as consisting essentially of a specified set of procedures, thus conceiving of democracy in procedural (Western liberal) terms. Other respondents were ambivalent about the meaning of democracy in substantial (emancipatory) or procedural (liberal) terms (IDASA Public Opinion Service 1996a:4-6 and 1996b:6-9).

South Africa's government generally respects the human rights of its citizens even though killings due to excessive use of force by security forces and deaths in police custody remains a problem in some areas. Levels of political violence have been reduced since 1998 but remain a problem in KwaZulu-Natal (U.S. State Department 2000a). Amnesty International (2000a) is more critical and reports that torture and unnecessary violence is still common among the South African police, that asylum-seekers and suspected illegal immigrants face official ill-treatment and racially motivated attacks, and that political violence still takes place in parts of the country.

On the economic front, South Africa has emerged out of the era of apartheidisolation as a thoroughly re-integrated player in the global economy (Koelble 1998), which has led to tensions between the ANC and its government allies, the SACP and COSATU. These tensions are illustrative of the effect of MWS forces on domestic relationships between state, capital and civil society in a semiperipheral country pressured by sharply divergent concerns of "core" and "periphery" segments of society. The emerging rift within the Tripartite Alliance is due to the ANC's acceptance of neoliberal economic growth policies as the only method capable of providing the resources needed to correct the inequalities created by centuries of race-based oppression while its allies pushes for highly redistributive policies (Ward 1998:50). Given the highly skewed income distribution in South Africa and the resulting low rate of domestic savings and investment, the country needed FDI. Hence pursuit of an "investor-friendly environment" and the adoption of the GEAR program in 1996.

South Africa has been better able to enhance the extractive capabilities of the state than have weaker (peripheral) countries. Instead of seeing its tax base shrink after liberation as has been common in other African countries, the South African government under President Nelson Mandela "has broadened the base by building an efficient collection agency outside the regular civil service" (Africa Confidential 1999c). The South African Revenue Service (SARS) collected a record R200 billion for the $1999 / 2000$ fiscal year. Revenue collection efficiency has been steadily improved over the last few years due to improvements in collection procedures and the combating of corruption and fraud (The Star 200I). Activists in civic organizations suggest that having a substantial tax base outside workers employed by government, which is uncommon in most African countries, is positive for democracy. "It helps democracy. If the government's taxing your income at source, there's more incentive to hold it to account for the way it's spending your money" (Africa Confidential 1999c). South Africa's semi-peripheral position in the MWS makes the country more likely to sustain such positive developments in terms of state capacity whereas peripheral countries (like Zambia) will likely see the continuation of poor extractive and distributive capabilities, thus further exacerbating state and civil society weakness, antagonistic class relations, and authoritarian tendencies.

South Africa's semi-peripheral role in the world economy can help with external affairs as well. The relationship between Washington D.C. and Pretoria has evolved into the closest relationship the U.S. has with any African country. The institutionalization of this relationship began with the Bi-National Commission launched by presidents Bill Clinton and Nelson Mandela in 1996 (Africa Confidential 1999a). Pretoria is also asserting its position in the semi-periphery by embracing "strategic partners," such as Argentina, Brazil, Britain, China, and Germany.

On the other hand, negotiations over trade relations between South Africa and the EU, assumed to become South Africa's core "benefactor" in terms of promoting a trade relationship conducive to South African development and democratic consolidation, have become increasingly conflictual since they begun in 1994. The EU wishes to export cheap manufactures to South Africa while at the same time protecting the EU market from competitive South African agricultural goods (Africa Confidential 1997a). The situation is illustrative of the pressures put on developing countries like South Africa today when world markets and their core-led representatives (e.g., the EU, U.S., IMF, and World Bank) insist on economic liberalization and openness. The inability to enjoy relatively higher levels of protection of home industries, as countries who in the past moved up rapidly in the global division of labor did (e.g., Japan and South Korea), gives semi-peripheral countries like South Africa an additional hurdle to overcome in their quest for economic development and democratic consolidation.

A democratizing country with a strong and diversified economy is more likely to balance the oftentimes conflicting demands of international and domestic capital and societal pressures for redistribution that might threaten the consolidation process, but South Africa's economic progress since the 1994 dem- 
ocratic transition has been anything but promising. ${ }^{19}$ Serious concerns about South Africa's economic viability, despite the U.S. identification of South Africa as one of ten "Big Emerging Markets" (BEM's) and the general goodwill displayed internationally towards South Africa's first true democratic government remain (McGowan and Ahwireng-Obeng I998a, 29-30).

While South Africa faces pressures related to globalization, the country does have an inherent advantage over peripheral states in that it can diffuse some of its internal costs to other states dependent on the South African economy in the region. McGowan and Ahwireng-Obeng (1998a and 1998b:167) argue that South African capital has been increasingly hegemonic in the southern African region since 1994 and that the present South African government strongly supports capital's economic aspirations.

South Africa's trade with the European Union (a key part of the core) and sub-Saharan Africa (part of the world's periphery) fits [the] worldsystem model of a semi-peripheral state and its paradoxical role in the world as both "exploited" and "exploiter" (McGowan and Ahwireng-Obeng 1998b:169).

Overall, South Africa's ability to diffuse some economic and political costs of democratization and economic restructuring onto peripheral neighbors in the SADC and beyond, coupled with its administratively capable state organization and indigenous capitalist class, indicates that democratic consolidation is a realistic goal likely to be attained. The role of core capital in South Africa also reflects the country's position in the MWS. Johannesburg is a "global city," and Cape Town less so, as sites of southern African operations of MNC's whereas no cities in peripheral Zambia play a similar role. The empirical evidence tentatively supports the prediction regarding South Africa possessing the resources necessary to consolidate its democracy. Of course, semi-peripheral status entails not only advantages vis-à-vis the periphery but also the existence of some of the similar problems characterizing the periphery and thus South Africa is by no means safe from democratic reversals. ${ }^{20}$

19. Growth rates have decreased from roughly 4 percent in 1995 to about I percent in I998 (Ginsberg 1998:4). While job growth in the government sector (which, due to less generation of actual revenue, is less desirable) has decreased from over 4 percent per year in the I970s to just over 2 percent per year in the early I990s; job growth in the (more desirable) private sector has declined from roughly I.5 percent to less than -2 percent (a total loss of jobs) in the same time frame (Ginsberg 1998:86).

20. Democratic consolidation in South Africa faces several challenges, most notably those relating to poverty, crime and health. When asked to list the most pressing problems South Africa faces, survey respondents consistently mention job creation/unemployment ( 75 percent) and crime (6I percent) as the top concerns. Housing comes in as a distant third concern (34 percent) (IDASA Opinion '99). The AIDS crisis is proving particularly devastating for the African

\section{Zambia}

On most accounts it seems clear that Zambia's democracy has fallen prey to all the potential dangers mentioned by Schedler (1998:9I), such as authoritarian regression and a "reverse wave." Many of the difficulties of consolidating democracy in Zambia relate to the country's status as one of the poorest in the world (UNDP 200I). In accordance with its peripheral location in the MWS, Zambia state has been weak and its vulnerable economic position and dependence on core donors and organizations has polarized civil society and worsened class relations.

The re-election of Chiluba in Zambia's second multiparty elections in November 1996 turned out to be quite problematic (Burnell 1996:407; Joseph 1999:6). President Chiluba's MMD triumphed at the polls after introducing a constitutional amendment that effectively barred former President Kaunda from running for president again. Chiluba was endorsed by 73 percent of the electorate and the MMD took control over I3I of the I5O seats in the National Assembly, a slight increase from 1991 (Baylies and Szeftel 1997:113).

Michael Bratton and Daniel Posner (1999:392) note that "[w] hile the MMD has scored some important successes in the area of economic reform, its performance on the political front has been regressive." In terms of what Zambia's second national elections in 1996 meant for democratic consolidation, " $\mathrm{t}]$ he answer is clear: they set the process back" (Bratton and Posner 1999:402). The tendency of the MMD to use its position in government (which entails access to strategic resources) to bully and intimidate political opposition resembles that of the typical peripheral state, using coercion to maintain its rule, as predicted by MWS theory.

Richard Joseph (1999:6) argues that while Chiluba's MMD could have opted for the maintenance of a constitutional democracy, the government has resorted to intimidation of journalists and civil society activists; it has arrested political opponents and has used mysterious bombings as a pretext for imposing states of emergency. Indeed,

[i]n six years, Chiluba has taken Zambia back to the worst period of what had been, by prevailing African standards, relatively mild authoritarian governance under Kaunda. What is more alarming is the ease with which Chiluba has manipulated voter support and development aid to withstand demands to follow a more democratic course (Joseph 1999:6).

continent. According to the World Health Organization, approximately 80 percent of all AIDS cases worldwide occur in sub-Saharan Africa. The southern African region is the hardest hit by AIDS today, and 20 percent of South Africa's adult population is HIV positive with about 2000 new infections occurring daily (UNAIDS 2000). 
The U.S. State Department (200ob) considers the Zambian government's human rights record as generally poor. The government has taken some steps to address these problems, but political rights were seriously infringed upon during the 1996 national elections, police killings and routine beatings and abuse of criminal suspects remain a widespread problem, and the independent press is harassed by the government through the courts. A state of emergency was declared in Zambia in October 1997 and lasted until March 1998 following an alleged coup plot on October 29. During this time government was granted freedom of action beyond the restrictions of constitutional rule. According to Amnesty International (200ob) there is still fallout from the trials of those accused of involvement in the 1997 coup attempt with several death sentences handed down. The drunken coup plot, leading to a purge of the Zambian military by President Chiluba, is illustrative of how weak peripheral states often fail to maintain domestic stability and in trying to do so relapse into authoritarian behavior which further alienates international donors that the state is economically dependent upon. The abuse of detainees in this case simply gave Western donors yet another reason to withhold aid (Africa Confidential 1997b).

Judging from recent developments the consolidation project has been a failure in Zambia and it remains doubtful whether Zambia can regroup and salvage the remains of the democratic transition that took place in 1991. The November 4, 1999 assassination of Major Wezi Kaunda (the son of former President Kenneth Kaunda) turned Zambia into a "political powder keg," Following allegations that Major Kaunda was involved in funneling aid to UNITA rebels in Angola and training guerillas in eastern Angola close to the Zambian border, the assassination might have been a pre-emptive strike aiming at preventing a military overthrow of Zambia's President Chiluba (Johannesburg Mail \& Guardian 1999). On July 6, 200I former MMD Deputy National Secretary Paul Tembo was assassinated in his Lusaka home by gunmen on the same day he was scheduled to testify before a tribunal investigating alleged large scale fraud by three MMD ministers in the Chiluba government (The Post [Lusaka] 2oorb). These events indicate that continued political volatility is to be expected in Zambia.

Zambia's impoverished economy and history of one-party rule means that the current government faces enormous challenges in terms of balancing the demands for liberalization by the international community with the redistributive demands of the Zambian citizenry. The government is heavily reliant upon other nations and non-governmental organizations for aid, loans, concessions, credit, and support (see Table 6). When the MMD promised delivery and improvements in living conditions by campaigning under the slogan "The Hour has come" it benefited from the frustration and alienation Zambians felt toward the previous regime and its inability to improve the economy, human rights and overall living conditions (Ihonvbere 1996:169-172). However, the "revolution of rising expectations" might result in increasing protests and instability if promises cannot be fulfilled. A volatile societal climate emerges in which the "normality" of democratic society fails to materialize, and as expected Zambia has not been as resilient as South Africa in terms of safeguarding initial democratic success.

IMF and World Bank demands for economic liberalization have resulted in significant privatization of copper mining assets in Zambia. While such privatization has boosted Zambia's competitiveness ranking to twelfth among 24 ranked African countries according to the Africa Competitiveness Report $2000 / 200$ ( World Economic Forum 2000), it runs the risk of (re)igniting political and economic rivalries (Africa Confidential 200ob) ${ }^{21}$ Quarrels between new and old copper mining interests that create societal unrest in Zambia's "copper belt" are the unfortunate outcome of policies (allegedly) designed to strengthen Zambia's economy. Instead the result might very well be a further weakening of Zambia's deteriorating democracy. Zambia Congress of Trade Unions (ZCTU) Deputy President Japhet Moonde echoes the concerns about negative effects of core-mandated reforms having a dire impact on Zambian society.

The economic reform measures under the MMD regime became synonymous with retrenchments, redundancies, and joblessness for the majority of Zambians where it is estimated that about 70 or 80 percent of Zambians live in absolute poverty today, a record that surpasses even the colonial era (The Post [Lusaka] 200Ia).

Countries like Zambia that have not established firm "ownership" of their reform programs are heavily dependent on external economic support in order for reform initiatives to be continually supported by the government, not to mention the populace. Difficulties associated with demands for structural adjustments and economic reforms result in the government blaming IFI's and international and local non-governmental organizations (NGO's) for "plotting" to sabotage the national economy (Africa Confidential 1999e). Zambia, due to its peripheral position in the MWS, is less capable than semi-peripheral South

21. The Africa Competitiveness Report 2000/200I, designed to predict medium to long term growth, ranks South Africa seventh and Zambia twelfth among 24 African countries surveyed. Zambia's relatively high position is due to its recently initiated privatization program. The report identifies South Africa as an Africa leader whose performance is very important for an African Renaissance. The report also addresses the issue of debt forgiveness that is considered key for continued economic progress on the continent. Jeffrey Sachs contends that the process of granting relief to heavily indebted poor countries (HIPC) remains inadequate. "The process is too slow, too stingy, and too arbitrary" as it does not properly take into account real social needs (World Economic Forum 2000). 
Africa of acquiring "ownership" and key, if not broad, support for neoliberal economic reforms.

Following the suspension of balance-of-payment support to Zambia by European donors after the problematic presidential election in 1996 and continued poor economic performance, the future of the Zambian government was at stake when the World Bank's consultative group met in Paris on May 26-28, 1999. Donors seemed somewhat pleased, however, and indicated that further support would be forthcoming pending Zambia's privatization of Zambia Consolidated Copper Mines (Africa Confidential I999d). Earlier on, the Zambian economy was surviving partly due to a US\$70 million IMF loan that was granted with the understanding that the sales of copper mines would be finalized by the end of March 1999 (Africa Confidential 1999b). The dependency of Zambia's government on international donors to shore up support for reforms was again manifested when only the promise of large sums of money to the Zambian government made at the Consultative Group meeting in Lusaka on July I6-I8, 2000 likely prevented the dismissal of Zambian Finance Minister Katele Kalumba and strengthened the position of the relatively few reformers in the government (Africa Confidential 200ob).

The typical "strong-arm" tactics employed by peripheral states like Zambia on the political front and in dealing with societal upheaval are partly the result of stresses associated with a dependent and vulnerable economic situation. A vicious cycle of economic dependence is set in motion, leading to desperate measures by the state that in turn exacerbate economic dysfunctionality. Thus, following privatization of the Zambian mines in March 2000 (selling major copper and cobalt businesses to South African Anglo American Plc and a CanadianSwiss consortium), international aid donors have now shifted their focus from Zambian macroeconomic policy initiatives to the government's human rights record (Johannesburg Mail \& Guardian 2000).

An examination of the empirical evidence of Zambia's transition to democracy and subsequent struggle to maintain and consolidate it supports the prediction that Zambia lacks resources necessary for consolidation. While the transition in Zambia is more directly linked to its economic vulnerability and susceptibility to external pressures than the South African one, it has also become clear that Zambia has not been able to diffuse the high costs of economic adjustment and democratization. The economic costs of Zambia's economic restructuring and democratic transition remain within the country, affecting a citizenry already desperate for improvements in living standards. The economy remains exposed to volatility, and as the state is unable to improve living standards conflict escalates and ultimately the government clamps down on civil society and democratic rights. Zambias peripheral status in the world-system is seemingly a key factor in explaining the country's struggle to break out of the vicious cycle of poverty and undemocratic governance.

\section{CONCLUSION}

South Africa shares many economic and social problems with peripheral countries. How can economic growth be encouraged while the government at the same time seeks redistribution as a means of uplifting its impoverished masses? South Africa also enjoys some of the advantages associated with semi-peripheral states; its economy is more diversified and modern than those of its peripheral neighbors and its modern administrative and commercial infrastructure makes it better positioned to compete in the global economy and to efficiently administer domestic economic and social activities. For South African democracy to prevail and fully consolidate, its leaders and citizens will have to carefully utilize the economic and political advantages that semi-peripheral status entails. The irony is that South African success will likely come at the partial expense of its peripheral neighbors (McGowan and Ahwireng-Obeng 1998b).

Zambia's misfortunes since the democratic transition in 1991 are illustrative of its inferior situation as a peripheral country. Zambia has remained a weak, vulnerable, and peripheral state where authoritarian leaders can prey upon the citizenry. Widespread poverty and peripheral status in the world-economy does not make successful democratization impossible (as Botswana, one of the world's poorest countries at independence, has shown), but in the case of Zambia all the weaknesses and disadvantages usually attributed to peripheral status seem to have combined to make successful democratization an elusive goal.

Overall we see that an inferior position in the global division of labor leads to state weakness and a drain on resources needed for development, and thus it also tends to have a disruptive impact on civil society and class relations. Using an MWS approach to understand processes of democratization is especially useful because it allows us not only to see the obvious linkage between higher socioeconomic development and democratic stability that modernization theory posits, but also how development in the non-core is greatly affected by decisions made in the core and how even some (short term) success with economic growth and management can be offset by the vulnerability and characteristic weaknesses that a peripheral position in the MWS entails.

The empirical evidence on the divergent democratization trajectories in South Africa and Zambia appears to support Hypothesis I somewhat and Hypothesis 2 more clearly. Based on the experience of South Africa it seems reasonable to suggest that semi-peripheral states are better equipped to mitigate external pressures for economic and political change and thus undertake democ- 
ratization on their "own terms." Based on the experience of Zambia, peripheral states are arguably much less able to democratize on their "own terms" due to a lack of economic resources and a weaker state and civil society.

The central irony of the MWS is manifested in these two case studies of democratic consolidation. The weakest states in the MWS can be pushed around by core powers and thus more easily forced to democratize (e.g., Zambia and many other African states). At the same time, these weak states are the least likely to possess the resources necessary to consolidate their democratic transition. On the other hand, semi-peripheral states can maintain their independence vis-à-vis the core to a higher degree (e.g., South Africa's decades long resistance to sustained internal and external pressures for democratization), but if the decision is made to undertake a democratic transition they are more likely to possess the resources necessary for successful consolidation.

Bringing back the research question that prompted this article: can a MWS approach help us explain processes of democratization within states? It becomes clear that the MWS approach has indeed been valuable, as the processes of democratization and consolidation in both South Africa and Zambia have been shaped by each country's position in the MWS. Of course, agency is not irrelevant, and Frederick Chiluba has not provided the leadership for Zambia that Nelson Mandela or (arguably) Thabo Mbeki have for South Africa. However, because location in the MWS matters, conventional (modernization) theories of democratization and consolidation that emphasize internal factors need to be revised and embrace a more holistic approach to democratization. To this end a MWS perspective can serve as a valuable theoretical complement.

The MWS approach underscores the importance of taking exogenous, systemic factors into serious consideration when discussing democratization and consolidation (cf. Martin 2000:258). This understanding ought to impact the way in which social scientists approach all societal phenomena that are global in nature:

For social scientists, internationalization of the world economy should sound the death-knell to the anachronistic divisions, institutionalized in universities, between "comparative politics" and "international relations." Cross-national comparisons are meaningless without placing the countries being compared in the context of a common world political economy within which they operate. Likewise, theories of international relations that treat all countries as fundamentally similar provide only limited insight into the variations in policy and institutional change. Neither comparative politics nor international relations can be coherently understood without aid from the other (Keohane and Milner 1996:257).
While it might seem obvious that states with more resources have a higher likelihood of consolidating democracy, the MWS approach is especially valuable for understanding the causal pathway between position in the MWS and democratic consolidation. Furthermore, the MWS approach is particularly useful for exposing the primary importance of factors such as external pressures and economic vulnerability. In the end, approaching democratic transitions and consolidation from a global perspective is necessary for discovering the secrets of democratic success and failure.

\section{REFERENCES}

Adam, Heribert, and Kogila Moodley. 1993. The Opening of the Apartheid Mind: Options for the New South Africa. Berkeley: University of California Press. Africa Confidential. 1997a. Trading places. Vol. 38, No. 6, I4 March. Africa Confidential. 1997b. Post-coup purge. Vol. 38, No. 24, i2 May. Africa Confidential. 1999a. /USA: Transatlantic tryst. Vol. 40, No. 5, 5 March. Africa Confidential. 1999b. Mining the depths. Vol. 40, No. 46, i9 March. Africa Confidential. 1999c. The fiscal fight. Vol. 40, No. 8, i6 April. Africa Confidential. 1999d. Down, not out. Vol. 40, No. II, 28 May. Africa Confidential. 1999e. Paris to Lusaka. Vol. 40, No. I2, in June. Africa Confidential. 2000a. Cash yes, reform? Vol. 4I, No. 15, 21 July. Africa Confidential. 200ob. Copper quarrels. Vol. 4I, No. 16, 4 August.

Africa Institute of South Africa. 1995. Africa at a Glance, 1995/96. Pretoria: Africa Institute of South Africa.

African Statistical Yearbook. 1998. Volume I (5).

AGOA. 200I. "African Growth and Opportunity Act," http://www.agoa.gov/About_

AGOA/about_agoa.html

Amnesty International. 2000a. "Annual Report: South Africa," http:// www.web.amnesty.org/web/ar2000web.nsf/7e6e3766b402ffb3802568f50061454 4/08b35cefab5ad412802568f20055296b? OpenDocument

Amnesty International. 200ob. "Annual Report: Zambia," http:// www.web.amnesty.org/web/ar2000web.nsf/7e6e3766b402ffb3802568f50061454 4/45ed97195d5b063a802568f200552986? OpenDocument

Arrighi, Giovanni, and Jessica Drangel. 1986. "The Stratification of the WorldEconomy: An Exploration of the Semiperipheral Zone." Review, ı, I (Summer): $9-74$.

Ayittey, George B. N. 1998. Africa in Chaos. New York: St. Martin's Press.

Baker, Bruce. 2000. "Can Democracy in Africa be Sustained?" Commonwealth E Comparative Politics, 38, 3: 9-34.

Bates, Robert. 1994. "The Impulse to Reform in Africa." In Economic Change and Political Liberalization in Sub-Saharan Africa, edited by Jennifer Widner. Baltimore: Johns Hopkins University Press. 
Baylies, Carolyn, and Morris Szeftel. 1997.“The 1996 Zambian Elections: Still Awaiting Democratic Consolidation."

Review of African Political Economy, 71: 113-128.

Bendix, Sonia. 1996. Industrial Relations in South Africa, $3^{\text {rd }}$ ed. Kenwynः Juta and Co, Ltd.

Bond, Patrick, 2000. Elite Transition: From Apartheid to Neoliberalism in South Africa. Pietermaritzburg: University of Natal Press.

Bjornlund, E., Michael Bratton, and C. Gibson. 1992."Observing Multi-Party Elections in Africa: Lessons from Zambia." African Affairs, 91: 405-43I.

Bratton, Michael. 1992. "Zambia Starts Over." Journal of Democracy, 3: 8I-94.

Bratton, Michael. 1994. "Economic Crisis and Political Realignment in Zambia." In Economic Change and Political Liberalization in Sub-Saharan Africa, edited by Jennifer Widner. Baltimore: Johns Hopkins University Press.

Bratton, Michael, and Nicolas van de Walle, eds. 1997. Democratic Experiments in Africa: Regime Transitions in Comparative Perspective. Cambridge: Cambridge University Press.

Bratton, Michael, and Daniel N. Posner. 1999. "A First Look at Second Elections in Africa, with Illustrations from Zambia." In State, Conflict, and Democracy in Africa, edited by Richard Joseph. Boulder: Lynne Rienner.

Broad, Robin, and John Cavanagh. 1999. "The Death of the Washington Consensus?" World Policy Journal, Fall: 79-88.

Burkhart, Ross E., and Michael S. Lewis-Beck. 1994. "Comparative Democracy: The Economic Development Thesis." American Political Science Review, 88, 4: 903-910.

Burnell, Peter. 1996. "Whither Zambia? The Zambian Presidential and Parliamentary Elections of November 1996." Electoral Studies, 16, 3: 407-416.

Butler, Anthony. 1998. Democracy and Apartheid: Political Theory, Comparative Politics and the Modern South African State. London: MacMillan Press LTD.

Chase, John C. 1967. Cape of Good Hope and Eastern Province of Algoa Bay. Cape Town: C. Struik (Pty*) Ltd.

Chase-Dunn, Christopher. 1975. "The Effects of International Economic Dependence on Development and Inequality: A Cross-National Study" American Sociological Review, 40, 6: 720-738.

Chase-Dunn, Christopher, and Richard Rubinson. 1977."Toward a Structura Perspective on the World-System." Politics E Society, 7, 4:453-476.

Chase-Dunn, Christopher. 198I. "Interstate System and Capitalist World-Economy: One Logic or Two?" International Studies Quarterly, 25, I* 19-42.

Chaudhry, Kiren. 1993. "The Myths of the Market and the Common History of Late Developers." Politics \& Society, 2I, September: 245-274.

Chirot, Daniel. 1977. Social Change in the Twentieth Century. New York: Harcourt, Brace and Jovanovich.

Chiwele, Dennis. 1996. "Economic Adjustment, the Mining Sector and the Real Wage in Zambia." In Constraints on the Success of Structural Adjustment Programmes in Africa, edited by Charles Harvey. London: MacMillan Press LTD.
Clapham, Cristopher. 1996. "Introduction: Liberalisation, regionalism and statehood in the new development agenda" Third World Quarterly, 17, 4: 593-602.

Commonwealth Observer Group. 1992. Presidential and National Assembly Elections in Zambia: The Report of the Commonwealth Observer Group. London: Commonwealth Secretariat.

COSATU. 2000. "Address by Thabo Mbeki, President of the ANC and of the Republic, to the COSATU $7^{\text {th }}$ National Congress," I8 September, 2000, http:// www.cosatu.org.za/congress/cong2000/tm000918.htm

Dahl, Robert. 1971. Polyarchy: Participation and Opposition. New Haven: Yale University Press.

Davidson, Basil. 1994. Modern Africa: A Social and Political History, $3^{\text {rd }}$ ed. London: Longman Group UK Limited.

Decalo, Stephen. 1992. "The Process, Prospects and Constraints of Democratization in Africa" Africa Affairs, 9, 362:7-35.

Deegan, Heather. 1999. South Africa Reborn: Building a New Democracy. London: University College London Press.

Denemark, Robert. 1991."The State in Zambia and Chile: The Role of Linkage to the World-Economy." Review, I4, 4: 517-554.

Deutsch, Karl W. 1964. "Social Mobilization and Political Development." American Political Science Review, 55: 493-514.

Diamond, Larry. 1999. Developing Democracy: Toward Consolidation. Baltimore: Johns Hopkins University Press.

Diamond, Larry, Marc Plattner, Yun-Han Chu, and Hung-Mao Tien, eds. 1997. Consolidating the Third Wave Democracies. Baltimore: Johns Hopkins University Press.

Di Palma, Guiseppe. 1990. To Craft Democracies. Berkeley: University of California Press.

European Commission. 2000. "European Initiative for Democracy and Human Rights: Compendium 200o," http://europa.eu.int/comm/europeaid/reports/ compendiu.pdf

Electoral Institute of Southern Africa. 2000. South African Local Government Elections 2000, http://www.eisa.org.za/saelect/localgovt/locgovt7k.htm

Esomba, S.N. 1995. Zambia Under Kaunda's Presidency: The Conditions, Experiments with Socialism, and the Final Lap to Democracy. Hamburg: LIT Verlag.

Frank, André Gunder. 1966. "The Development of Underdevelopment." Monthly Review, September: 17-3I.

Frank, André Gunder. 1967. Capitalism and Underdevelopment in Latin America. New York: Monthly Review Press.

Freedom House, 200I. Annual Survey of Freedom Country Ratings 1972-73 to 1999-00, http://www.freedomhouse.org/pdf_docs/research/ratings.pdf

Friedman, Steven. 1999. "South Africa: Entering the Post-Mandela Era." Journal of Democracy, IO, 4:3-18.

Gelb, Stephen, ed. 1991. South Africa's Economic Crisis. Cape Town: David Philip. 
Gelb, Stephen. 1994. "Development Prospects for South Africa." Paper presented to WIDER workshop on Medium Term Development Strategy, Phase II, Helsinki, April I5-I7.

Ginsberg, Anthony* 1998. South Africa's Future: From Crisis to Prosperity. London: MacMillan Press LTD.

Gissinger, Ranveig, and Nils Petter Gleditsch. 1999."Globalization and Conflict:

Welfare, Distribution, and Political Unrest." Journal of World-Systems Research, 5, 2: 327-365. http://jwsr.ucr.edu/

Gould, Carol. 1988. Rethinking Democracy: Freedom and Social Cooperation in Politics, Economics, and Society. Cambridge: Cambridge University Press.

Goma, Richard, and Joan Font. 1996. "Political Change and Socioeconomic Policies in Central America: Patterns of Interaction." Third World Quarterly, 17: 737-75I.

Gourevitch, Peter. 1978. "The Second Image Reversed: The International Sources of Domestic Politics." International Organization, 32, 4: 88I-9I2.

Grosh, Barbara. 1994."Through the Structural Adjustment Minefield: Politics in an Era of Economic Liberalization. In Economic Change and Political Liberalization in SubSaharan Africa, edited by Jennifer Widner. Baltimore: Johns Hopkins University Press.

Haggard, Stephan, and Robert Kaufman. 1995. The Political Economy of Democratic Transitions. Princeton: Princeton University Press.

Hamalengwa, Munyonzwe. 1992. Class Struggles in Zambia 1889-1989 E The Fall of Kenneth Kaunda 1990-9I. Lanham: University Press of America.

Hanson, Margaret, and James Hentz. 1999. "Neocolonialism and Neoliberalism in South Africa and Zambia." Political Science Quarterly, II4, 3* 479-502.

Hopkins, Terence, and Immanuel Wallerstein. 1982."Cyclical Rhythms and Secular Trends of the Capitalist World-Economy: Some Premises, Hypotheses, and Questions." In World-System Analysis: Theory and Methodology, edited by Terence Hopkins, Immanuel Wallerstein, R. Bach, Christopher Chase-Dunn, and R. Mukherjee. Beverly Hills: Sage.

Huber, Evelyne. 1996. "Options of Social Policy in Latin America: Neoliberal versus Social Democratic Models." In Welfare States in Transition: National Adaptations in Global Economies, edited by Gösta Esping-Andersen. London: Sage.

Huntington, Samuel. 1984. "Will More Countries Become Democratic?" Political Science Quarterly, 99, 2: 193-218.

Huntington, Samuel. 1989. "The Modest Meaning of Democracy." In Democracy in the Americas: Stopping the Pendulum, edited by R.A. Pastor. New York: Holmes and Meier.

Huntington, Samuel. 1991. The Third Wave: Democratization in the Late Twentieth Century. Norman: University of Oklahoma Press.

Hyden, Göran, and Michael Bratton, eds. 1992. Governance and Politics in Africa. Boulder: Lynne Rienner.

IDASA Public Opinion Service. 1996a."Building a Democratic Culture in the Western Cape: The Present Terrain," May 8
IDASA Public Opinion Service. 1996b."Building a Democratic Culture in KwaZulu/ Natal: The Present Terrain," June 9.

IDASA Opinion '99. 1998. Party Support and Voting Intention, November II, http: //www.idasa.org.za/pos/op99/op99_no4.htm

IDASA Opinion '99. 1999. The Public Agenda (II), January 28, http:// www.idasa.org.za/pos/op99/op99 no13.htm

Ihonvbere, Julius. 1996. Economic Crisis, Civil Society, and Democratization: The Case of Zambia. Trenton: Africa World Press, Inc.

Inglehart, Ronald. 1997. Modernization and Postmodernization: Cultural, Economic, and Political Changes in 43 Societies. Princeton: Princeton University Press.

Inkeles, Alex. 1964."Making Men Modern." In Social Change, edited by Amitai Etzioni and Eva Etzioni. New York: Basic Books.

International Monetary Fund. 200Ia. South Africa: Position in the Fund, http://www.imf.org/external/np/tre/tad/exfin2.cfm?memberKey1=880

International Monetary Fund. 200Ib. Zambia: Position in the Fund, http://www.imf.org/external/np/tre/tad/exfin2.cfm?memberKey1=1080

International Trade Centre. 2000a. National Trade Performances, http://www.intracen.org/mas/toolpd98/zaf 4.pdf and http://www.intracen.org/ mas/toolpd98/zmb_4.pdf

International Trade Centre. 20oob. International Trade Statistics, http://www.intracen.org/itc/tradstat/sitc3-3d/ir711.htm and http://www.intracen.org/itc/tradstat/sitc3-3d/ir894.htm

Johannesburg Mail \& Guardian. 1999. "Zambia balanced on a knife-edge," November 5, http://wwwmg.co.za/mg/news/99nov1/5nov-kaunda.html

Johannesburg Mail E Guardian. 2000. "Donors shift conditions for Zambia aid," June I, http://www.mg.co.za/mg/news/2000jun1/1jun-zambia.html

Johnson, R.W., and Laurence Schlemmer, eds. 1996. Launching Democracy in South Africa: The First Open Election, April 1994. New Haven: Yale University Press.

Jones, Stephen. 1994. "Structural Adjustment in Zambia." In Negotiating Structural Adjustment in Africa, edited by Willem van der Geest. London: James Currey.

Joseph, Richard. 1997. "Democratization in Africa after 1989: Comparative and Theoretical Perspectives." Comparative Politics, 29, 3:363-382.

Joseph, Richard. 1999. "Africa 1990-1997: From Abertura to Closure." In Democratization in Africa, edited by Larry Diamond and Marc Plattner. Baltimore: Johns Hopkins University Press.

Joseph, Richard. 1999b. "The Reconfiguration of Power in Late Twentieth-Century Africa." In State, Conflict, and Democracy in Africa, edited by Richard Joseph. Boulder: Lynne Rienner.

Keohane, Robert, and Helen Milner, eds. 1996. Internationalization and Domestic Politics. Cambridge: Cambridge University Press.

Kick, Edward L., Byron L. Davis, Marlene Lehtinen, and Thomas J. Burns. "WorldSystem Position, National Political Characteristics and Economic Development Outcomes." Journal of Political and Military Sociology, 28, I (Summer): 13I-I55. 
Klepper, Robert. 1979. “Zambian Agricultural Structure and Performance.” In Development in Zambia, edited by Ben Turok. London: Zed Press.

Koelble, Thomas. 1998. The Global Economy and Democracy in South Africa. New Brunswick: Rutgers University Press.

Kotelo, K. 1995."The Reshaping of Trade Relations in Southern Africa." Bulleting of the Africa Institute, South Africa, 35, 6: 10-II.

Lerner, Daniel. 1968. The Passing of Traditional Society: Modernizing the Middle East. New York: The Free Press.

Lijphart, Arend. 197I. "Comparative Politics and the Comparative Method." American Political Science Review, 65:682-693.

Lijphart, Arend. 1975. "The Comparable Cases Strategy in Comparative Research." Comparative Political Studies, 8, 2: 158-174.

Lipset, Seymour M. 1959. "Some Social Requisites of Democracyः Economic Development and Political Legitimacy." The American Political Science Review, 53, I: 69-105.

Londregan, John B., and Keith T. Poole. 1996. "Does High Income Promote Democracy?” World Politics, 49, I* I-30.

Mair, Stefan. 1996. "African Between Structural Adjustment, Democratisation and State Disintegration. Aussenpolitik, II: I75-I85.

Marais, Hein. 1998. South Africa: Limits to Change-The Political Economy of Transition. Cape Town: University of Cape Town Press.

Martin, William G., and Immanuel Wallerstein. 1990. "Southern Africa in the WorldEconomy, 1870-2000: Strategic Problems in World-Historical Perspective." In Breaking the Links: Development Theory E Practice in Southern Africa, edited by Robert E. Mazur. Trenton: Africa World Press, Inc.

Martin, William G. 2000. "Still Partners and Still Dissident After All These Years? Wallerstein, World Revolutions and the World-Systems Perspective." Journal of World-Systems Research. Special Issue: Festschrift for Immanual Wallerstein, vi, 2: 234-263. http://jwsr.ucr.edu/

Mattes, Robert, and Hermann Thiel. 1998. "Consolidation and Public Opinion in South Africa." Journal of Democracy, 9, Iः 95-109.

McGowan, Patrick, and Fred Ahwireng-Obeng. 1998a. "Partner or Hegemon? South Africa in Africa (Part One)." Journal of Contemporary African Studies, 16, I: 5-38.

McGowan, Patrick, and Fred Ahwireng-Obeng. 1998b. "Partner or Hegemon? South Africa in Africa (Part Two)." Journal of Contemporary African Studies, 16, 2‡ 165-195.

Melchior, Arne, Kjetil Telle, and Henrik Wiig. 2000. "Globalisation and Inequality: World Income Distribution and Living Standards, 1960-1998." Royal Norwegian Ministry of Foreign Affairs, Studies on Foreign Policy Issues, Report 6B (October).

Mkandawire, Thandika. 1999. "Crisis Management and the Making of 'Choiceless Democracies." In State, Conflict, and Democracy in Africa, edited by Richard Joseph. Boulder: Lynne Rienner.

Moore, Barrington. 1966. Social Origins of Dictatorship and Democracy: Lord and Peasant in the Making of the Modern World. Boston: Beacon Press.
Divergent Paths of Development

Muller, Edward. 1985. "Income Inequality, Regime Repressiveness, and Political Violence." American Sociological Review, 50, I* 47-6I.

Muller, Edward. 1995a. "Economic Determinants of Democracy." American Sociological Review, 60, 6: 966-982.

Muller, Edward. 1995b. "Income Inequality and Democratization: Reply to Bollen and Jackman." American Sociological Review, 60, 6: 99I-996.

O'Donnell, Guillermo. 1979. "Tensions in the Bureaucratic Authoritarian State and the Question of Democracy." In The New Authoritarianism in Latin America, edited by David Collier. Princeton: Princeton University Press.

Pateman, Carole. 1970. Participation and Democratic Theory. Cambridge: Cambridge University Press.

Peters, B. Guy. "The Civil Service in the Consolidation of Democracy." International Social Science Journal, 47: 127-140.

Price, Robert. 1991. "The Apartheid State in Crisis: Political Transformation in South Africa, 1975-1990." New York: Oxford University Press.

Przeworski, Adam. 1991. Democracy and the Market: Political and Economic Reforms in Eastern Europe and Latin America. Cambridge: Cambridge University Press.

Przeworski, Adam, Michael Alvarez, José Antonio Cheibub, and Fernando Lemongi. 1996. "What Makes Democracies Endure?" Journal of Democracy, 7, January: 39-55.

Reynolds, Andrew, ed. 1994. Election '94 South Africa. London: James Currey Ltd.

Rodney, Walter. 1972. How Europe Underdeveloped Africa. Washington: Howard University Press.

Rostow, W. W. 1964. "The Takeoff into Self-Sustained Growth." In Social Change, edited by Amitai Etzioni and Eva Etzioni. New York: Basic Books.

Rueschemeyer, Dietrich, Evelyne Huber Stephens, and John Stephens. 1992. Capitalist Development and Democracy. Chicago: The University of Chicago Press.

Sandbrook, Richard. 1985. The Politics of Africa's Economic Stagnation. Cambridge: Cambridge University Press.

Sandbrook, Richard. 1993. The Politics of Africa's Economic Recovery. Cambridge: Cambridge University Press.

Schedler, Andreas. 1998. "What is Democratic Consolidation?" Journal of Democracy, 9, 2: 9I-107.

Schumpeter, Joseph. 1947. Capitalism, Socialism, and Democracy. $2^{\text {nd }}$ ed. New York: Harper.

Schwartzman, Kathleen C. 1998. "Globalization and Democracy”. Annual Review of Sociology, 24: 159-18I.

Seidman, Ann. 1979. The Distorted Growth of Import Substitution: The Zambian Case. In Development in Zambia, edited by Ben Turok. London: Zed Press.

Shannon, Thomas. 1996. An Introduction to the World-System Perspective, $2^{\text {nd }}$ ed. Boulder: Westview Press.

Skocpol, Theda. 1973. "A Critical Review of Barrington Moore's 'Social Origins of Dictatorship and Democracy." Politics and Society, 12, 2. 
Snyder, David, and Edward L. Kick. 1979. "Structural Position in the World System and Economic Growth, 1955-1970: A Multiple-Network Analysis of Transnational Interactions." American Journal of Sociology, 84, 5ः 1096-II26.

Stadler, Alf. 1987. The Political Economy of Modern South Africa. New York: St. Martin's Press.

Southall, Roger. 2000. "The State of Democracy in South Africa." Commonwealth E Comparative Politics, 38, 3\%147-170.

South African Department of Finance. 1998. 1998 Southern Africa Economic Summit, Windhoek, Namibia, May 17-19, http://www.finance.gov.za/f/02/02/summits/ windhoek/southafrica.htm and http://www.finance.gov.za/f/02/02/summits/ windhoek/zambia.htm

Terlouw, C. P. 1993."The Elusive Semiperiphery: A Critical Examination of the Concept Semiperiphery." International Journal of Comparative Sociology, 34, I-2: 87-102.

The Economist. 1995. July I.

The Post (Lusaka), 20ora."The Economy is Becoming Informalised," May 25, http:// www.allafrica.com/stories/printable/200105250241.html

The Post (Lusaka). 20oib. "Assassins Kill Paul Tembo", July 6, http://www.allafrica.com/ stories/printable/200107060337.html

The Star. 200I. "Revenue service pulls in record R20obn." March I9.

The Sunday Independent. 200I. "SA's economy will never be the same." February 24.

Tordoff, William. 1997. Government and Politics in Africa. $3^{\text {rd }}$ ed. Bloomington: Indiana University Press.

UNAIDS. 2000."Epidemiological Fact Sheet on HIV/AIDS and sexually transmitted infections: South Africa," http://www.unaids.org/hivaidsinfo/statistics/june00/ fact sheet/pdfs/southafrica.pdf

United Nations Development Programme. 1999. Human Development Report, http: //www.undp.org/hdro/report.html

United Nations Development Programme. 2000. Human Development Report, http: //www.undp.org/hdr2000/english/book/back1.pdf

United Nations Development Programme, 200I. Human Development Report, http: //www.undp.org/hdr2001/back.pdf

United Nations Economic Commission for Africa. 1996. Economic and Social Survey of Africa, 1995/96. Addis Ababa: United Nations.

USAID. 200I. "Democracy \& the U.S. National Interest," http://www.usaid.gov/ democracy/dusni.html

U.S. Department of State, 2000a+ 1999 Country Reports on Human Rights Practices, http://www.state.gov/www/global/human rights/1999 hrp report/ southafr.html

U.S. Department of State. 2000b. 1999 Country Reports on Human Rights Practices, http://www.state.gov/www/global/human rights/1999 hrp report/ zambia.html

van de Walle, Nicolas. 1999a."Economic Reform in a Democratizing Africa," Comparative Politics, 32, I* 2I-4I. van de Walle, Nicolas. 1999b. "Globalization and African Democracy." In State, Conflict, and Democracy in Africa, edited by Richard Joseph. Boulder: Lynne Rienner.

van Evera, Stephen. 1997. Guide to Methods for Students of Political Science. Ithaca: Cornell University Press.

Vanhanen, Tatu. 1997. Prospects of Democracy: A Study of I72 Countries. London: Routledge.

Waldmeir, Patti. 1997. Anatomy of a Miracle: The End of Apartheid and the Birth of the New South Africa. New York: W. W. Norton \& Company.

Wallerstein, Immanuel. 1974a. The Modern World System I: Capitalist Agriculture and the Origins of the European World-Economy in the Sixteenth Century. New York: Academic Press.

Wallerstein, Immanuel. 1974b. “The rise and future demise of the world capitalist system: concepts for comparative analysis." Comparative Studies in Society and History, I6, 4: 387-415.

Wallerstein, Immanuel. 1979. The Capitalist World-Economy. New York: Cambridge University Press.

Wallerstein, Immanuel. 1984. "Patterns and Prospectives of the Capitalist WorldEconomy." Contemporary Marxism, 9: 59-70.

Wallerstein, Immanuel. 1986. Africa and the Modern World. Trenton: Africa World Press, Inc.

Wallerstein, Immanuel. 1993. "The Present State of the Debate on World Inequality. In Development and Underdevelopment: The Political Economy of Inequality, edited by M. A. Seligson and J. T. Passé-Smith. Boulder: Lynne Rienner.

Ward, Alan. 1998. "Changes in the Political Economy of the New South Africa." In The New South Africa, edited by F. H. Toase and E. J. Yorke. London: MacMillan Press LTD.

Widner, Jennifer, ed. 1994. Economic Change and Political Liberalization in Sub-Sabaran Africa. Baltimore: Johns Hopkins University Press.

World Bank. 1994. Adjustment in Africa: Reforms, Results, and the Road Abead. Oxford: Oxford University Press.

World Bank. 1999. World Development Report 1999/2000: Entering the 2I ${ }^{\text {st }}$ Century. Washington D.C.: World Bank.

World Bank, 2000, Can Africa Claim the $2 \mathrm{I}^{\text {st }}$ Century. Washington, D.C.: World Bank.

World Economic Forum, 2000. The Africa Competitiveness Report 2000/200I: Strengths and Challenges Facing the Continent. New York: Oxford University Press.

Young, Crawford. 1994. "Democratization in Africa: The Contradictions of a Political Imperative." In Economic Change and Political Liberalization in Sub-Saharan Africa, edited by Jennifer Widner. Baltimore: Johns Hopkins University Press.

Young, Crawford. 1999. "The Third Wave of Democratization in Africa: Ambiguities and Contradictions.' In State, Conflict, and Democracy in Africa, edited by Richard Joseph. Boulder: Lynne Rienner. 